\title{
HYDROCARBON AND SULFUR SENSORS FOR SOFC SYSTEMS
}

\author{
Phase I Final Report
}

Reporting Period: October, 2002-October, 2003

Principal Authors:

A.-M. Azad, Chris Holt, Todd Lesousky, and Scott Swartz

Report Issued: November, 2003

SECA Phase I Core Technology Project

DOE Contract No. DE-FC26-02NT41576

NexTech Materials, Ltd.

404 Enterprise Dr.

Lewis Center, $\mathrm{OH} 43035$.

Phone: (614) 842-6606

Fax: (614) 842-6607

swartz@nextechmaterials.com 


\section{Disclaimer}

"This report was prepared as an account of work sponsored by an agency of the United States Government. Neither the United States Government nor any agency thereof, nor any of their employees, makes any warranty, express or implied, or assumes any legal liability or responsibility for the accuracy, completeness, or usefulness of any information, apparatus, product, or process disclosed, or represents that its use would not infringe privately owned rights. Reference herein to any specific commercial product, process, or service by trade name, trademark, manufacturer, or otherwise does not necessarily constitute or imply its endorsement, recommendation, or favoring by the United States Government or any agency thereof. The views and opinions of authors expressed herein do not necessarily state or reflect those of the United States Government or any agency thereof." 


\section{Table of Contents}

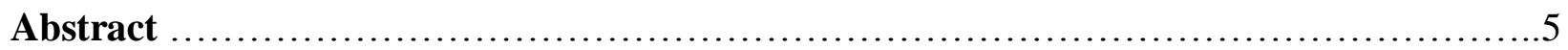

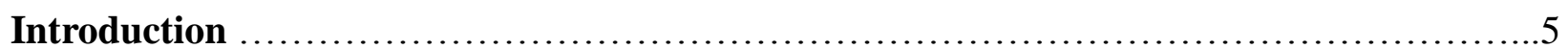

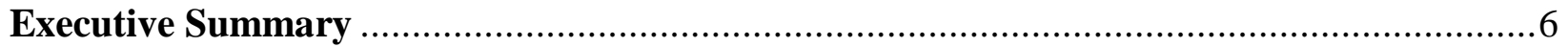

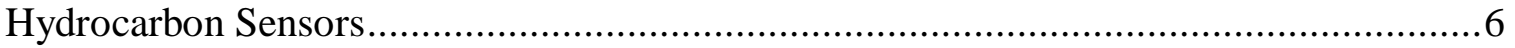

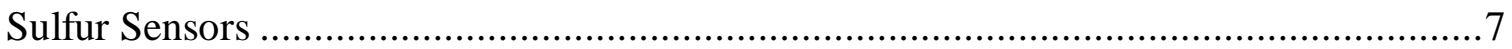

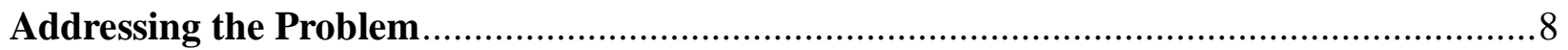

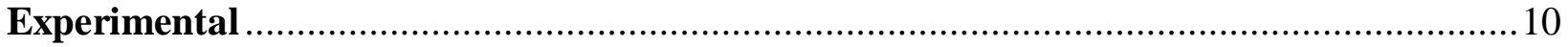

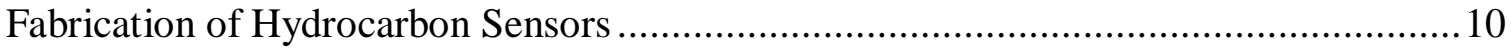

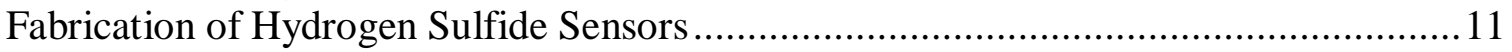

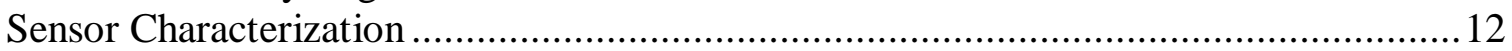

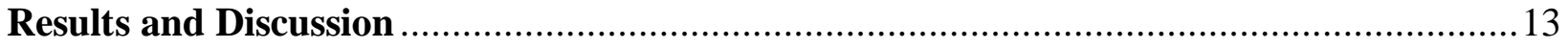

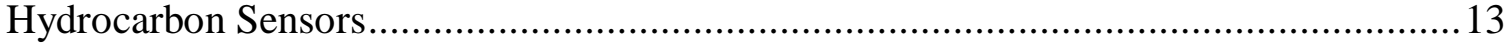

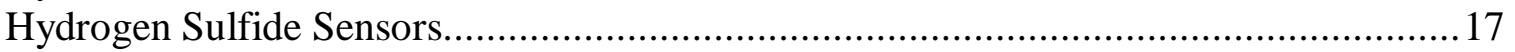

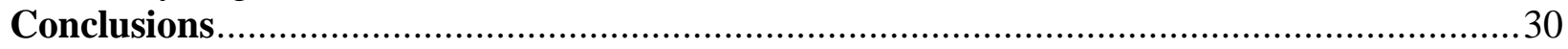

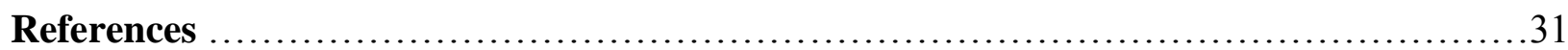

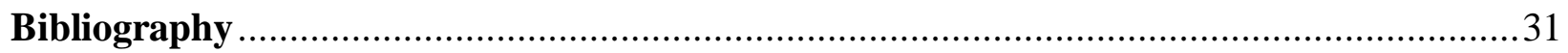

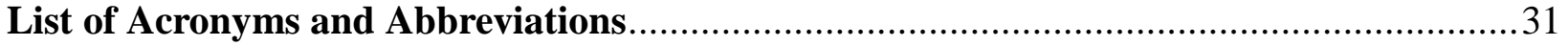

\section{List of Graphical Materials (Tables)}

Table 1. Status of Sensor Technology Development ................................................. 8

Table 2. Summary of Results for Various $10 \% \mathrm{Al}_{2} \mathrm{O}_{3}-5 \% \mathrm{MoO}_{3}-\mathrm{GDC}$ samples at $500{ }^{\circ} \mathrm{C} . .24$

\section{List of Graphical Materials (Figures)}

Figure 1. Sensing model of a semiconducting material showing the depletion region and energy

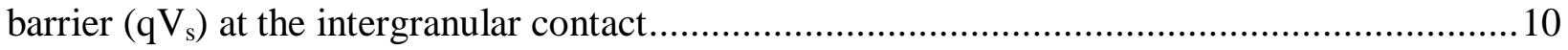

Figure 2. NexTech "Fuel Cell" hydrocarbon sensor design ........................................... 11

Figure 3. Schematic of a chemi-resistive sensor on an alumina substrate with Au-electrodes ... 12

Figure 4. Assembly of a bench-top gas sensing apparatus ............................................. 13

Figure 5. Sensitivity of a Ni/YSZ anode-based fuel cell sensor to $4.4 \% \mathrm{CH}_{4} \ldots \ldots \ldots \ldots \ldots \ldots \ldots . . \ldots \ldots$

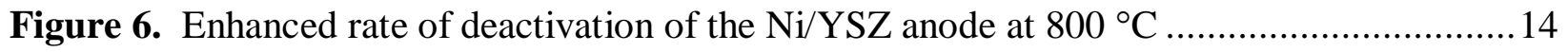

Figure 7. Stable performance of Ni/GDC anode towards $\mathrm{CH}_{4}$ in syngas up to $800{ }^{\circ} \mathrm{C} \ldots \ldots \ldots \ldots . . . .15$

Figure 8. Response of $\mathrm{CuO} / \mathrm{GDC}$ anode in the presence of $3.6 \% \mathrm{CH}_{4}$ in reformate................ 15

Figure 9. Phase stability of $\mathrm{La}_{0.90} \mathrm{Sr}_{0.10} \mathrm{CrO}_{3}$ during long-term reaction studies in syngas..........16

Figure 10. Response of $\mathrm{Sr}$-substituted $\mathrm{LaCrO}_{3}$ anode film to $4-10 \% \mathrm{CH}_{4}$ at $550{ }^{\circ} \mathrm{C} \ldots \ldots \ldots \ldots \ldots 16$

Figure 11. Response at $350{ }^{\circ} \mathrm{C}(12$ successive repeatable cycles $)$........................................ 18

Figure 12. Repeatable response of the sensor at $420^{\circ} \mathrm{C}$.................................................. 18

Figure 13. Response of $5 \% \mathrm{MoO}_{3}-\mathrm{GDC}$ film on day 3 at $350{ }^{\circ} \mathrm{C}$.....................................19

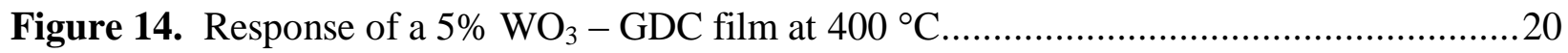

Figure 15. Response of a Na-catalyzed $\mathrm{MoO}_{3}-\mathrm{GDC}$ to $10 \mathrm{ppm}_{2} \mathrm{~S}$ in $20 \% \mathrm{H}_{2}$ background ..20

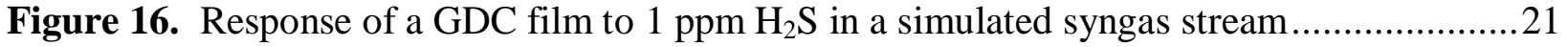


Figure 17. Correlation between baseline and sensitivity for Base Sample in $5 \mathrm{ppm}_{2} \mathrm{~S}$ and $2 \%$

$\mathrm{H}_{2} \mathrm{O}$

Figure 18. Correlation between baseline and sensitivity for Base Sample in $10 \mathrm{ppm}_{2} \mathrm{~S}$ and $2 \%$

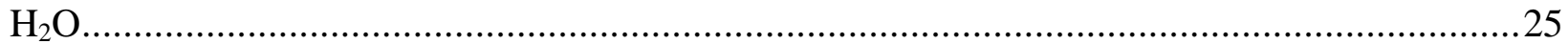

Figure 19. Plot of the Response of Sensor 125-103A to 5 and $10 \mathrm{ppm} \mathrm{H}_{2} \mathrm{~S}$...........................26

Figure 20. Response of Sensor 125-82D over several days to $5 \mathrm{ppm} \mathrm{H}_{2} \mathrm{~S}$..............................26

Figure 21. Response of Sensor 125-103A over several days to $5 \mathrm{ppm} \mathrm{H}_{2} \mathrm{~S} \ldots \ldots \ldots \ldots \ldots \ldots \ldots \ldots \ldots \ldots . . .27$

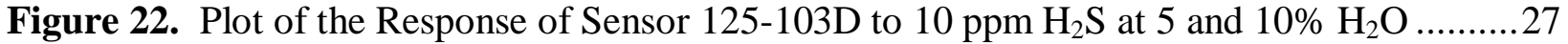

Figure 23. XRD pattern for $10 \mathrm{wt} \% \mathrm{MoO}_{3}$ with GDC showing conversion of $\mathrm{MoO}_{3}$ into

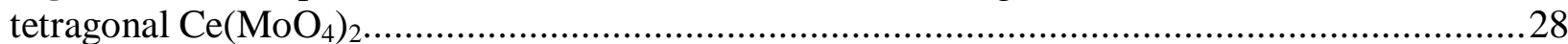

Figure 24. Sensor signal conditioning circuit schematic showing Wheat-stone bridge, amplification, analog to digital, and PIC conversion

Figure 25. Sensor heater and signal conditioning hardware. .30 


\begin{abstract}
The following report summarizes work conducted during the Phase I program Hydrocarbon and Sulfur Sensors for SOFC Systems under contract No. DE-FC26-02NT41576. For the SOFC application, sensors are required to monitor hydrocarbons and sulfur in order to increase the operation life of SOFC components. This report discusses the development of two such sensors, one based on thick film approach for sulfur monitoring and the second galvanic based for hydrocarbon monitoring.
\end{abstract}

\title{
INTRODUCTION
}

Fuel cells are quiet, environmentally clean and highly efficient devices for generating electricity and heat from natural gas, biomass, and other hydrocarbon fuels. They are vastly different from other power sources and offer a promising viable alternative to internal combustion power generation processes. A fuel cell is an electrochemical device that converts the chemical energy of a fuel directly into energy - electricity and heat - without combustion or moving parts. Hydrogen has been touted to be the ideal fuel for running fuel cells. However, our present infrastructure for producing enough hydrogen to support large markets is years or even decades away. Therefore, hydrocarbon fuels must first be converted (or reformed) into a hydrogen-rich gas consisting of little or no impurities (e.g., sulfur). In addition, catalysts used for reforming heavy hydrocarbons are poisoned by the sulfur content contained in gasoline and diesel fuels (mostly as organosulfur). During reforming process, sulfur is also likely to be transformed into $\mathrm{H}_{2} \mathrm{~S}$, which in turn is responsible for the unpleasant odor in the fuel. The level of sulfur contamination is much less ( up to $1 \%$ ) in gasoline and diesel fuel, while in gasified coal it varies between $2.3 \%$ and $4.5 \%$ depending upon the quality and type of coal. In addition, the escape of lighter hydrocarbons leads to coke-formation at the anode in SOFCs. This, in combination with sulfidation, renders the anode deactivated compromising the efficiency of the fuel cell. Thus, a need exists to remove these species from the reformed fuel before they reach the anode. Equally important in this process is the detection and continuous monitoring of these species at various locations in the reformer-SOFC loop. This requires the development of reliable and rugged sensors that would be mechanically robust and could withstand the harsh reducing environment in the temperature regime of $\sim 650-800{ }^{\circ} \mathrm{C}$.

For SOFC-based power systems (operating temperatures $750{ }^{\circ} \mathrm{C} \leq \mathrm{T} \leq 1000{ }^{\circ} \mathrm{C}$ ), hydrogen is the most ideal fuel. However, this requires reforming hydrocarbon fuels utilizing multiple catalytic reactors. At the end of the reforming stage, there are also gases such as unburned hydrocarbons $\left(\mathrm{C}_{\mathrm{x}} \mathrm{H}_{\mathrm{y}}\right), \mathrm{H}_{2} \mathrm{~S}$ and $\mathrm{SO}_{2}$ (from sulfur impurities in the fuel), $\mathrm{NO}_{\mathrm{x}}$ and $\mathrm{NH}_{3}$ ranging in levels between several hundred ppm to subppm. If such a complex gas mixture is allowed to penetrate a fuel cell system, many of the impurities are likely to adversely affect the performance of the device and/or increase the amount of environmental pollution. For instance, lighter hydrocarbons have a tendency to create coke-formation on the anode; a large excess of steam is required to prevent carbon deposition and subsequent catalyst degradation. Further, the catalysts used for reforming heavy hydrocarbons are poisoned by sulfur present (mostly as organosulfur) in gasoline and diesel fuels and therefore necessitates the use of precious metal catalysts, and/or operation of 
these catalytic reactors at higher temperatures, to decrease sulfur poisoning. Since the development of coke-formation resistant and sulfur-tolerant fuel cell anodes is still in the embryonic stage, on-line monitoring of lighter hydrocarbons and introduction of sulfur sensors at strategic locations would form an important quality control tool for the reforming operation as it relates to anode degrading species, and is also expected to enhance the process efficiency via feedback between sensors and the process control unit. As a result, sulfur sensors providing real time feedback could monitor a desulfurizer that is placed between the reformer and the fuel cell for sulfur removal.

\section{EXECUTIVE SUMMARY}

Recognizing the above-mentioned difficulties in realizing a sensor that operates in reducing environments and in order to eliminate or greatly minimize the reducibility of the sensor film by hydrogen, novel strategies and formulation were devised. The following executive summary outlines the results of Phase I in the context of feasibility assessment.

Due to the complex nature of the gas stream in reformate and fuel cell stacks, and the highly dynamic (and hence non-equilibrium) conditions associated with SOFC operation, it is rather difficult to conceive of a single material or a solitary technique that would address sensing and metering needs throughout the SOFC system. Therefore, in Phase I, a strategy involving several potential materials and viable techniques was proposed to meet the goals. For HCs, commercially available $\mathrm{SiC}$ and $\mathrm{Si}_{3} \mathrm{~N}_{4}$ were proposed as sensors in current-voltage (I-V) mode. For fabricating the sulfur sensor, galvanic cells with $\mathrm{Ag}^{+}$-ion conducting $\beta$ or $\beta$ "-alumina electrolyte with suitable coexisting phases and reference electrodes were designed. However, it soon became clear that these methodologies were not adequate, considering the mitigating conditions under which these sensors were required to operate: high temperatures, high gas velocity, fast changing gas composition and highly reducing (predominantly $\mathrm{H}_{2}$-rich) environments. In the latter case, reaction of $\mathrm{Ag}^{+}-\beta$ "-alumina electrolyte with $\mathrm{H}_{2} \mathrm{~S}$, severe decomposition of coexisting $\mathrm{Ag}_{2} \mathrm{~S}$ in the test electrode by $\mathrm{H}_{2}$, difficulty in sealing of the cell and isolation of the two electrode compartments, were some of the serious issues that needed more time and efforts than could be afforded during phase I timeline. It should also be pointed out several variations of the galvanic cell technique with different solid electrolytes and electrode systems were attempted but none led to a successful test module, since several of the above mentioned problems remained unsolved. A change of strategy led to the successful development of reliable sensors for methane and hydrogen sulfide both, as explained in the following.

\section{Hydrocarbon Sensors}

In the case of hydrocarbon sensor, the concept is based on employing a stabilized zirconia-based fuel cell set up, using $\mathrm{H}_{2}$ as the fuel, contaminated with varying levels of methane (the first model hydrocarbon to be tested) and air as the oxidant. Initially, the sensor design differed from the conventional fuel cell operation in that instead of one anode (as in the fuel cell) it consisted of 'two' anodes. One anode was chosen to be somewhat inert toward hydrocarbon poisoning (and hence would give near theoretical open circuit potential), while the other would be the one known to undergo degradation in presence of $\mathrm{HC}$ species in the fuel stream. Thus, by measuring simultaneously the open circuit potential of two 'half cells', the difference in the voltage output 
would be a function of the presence of hydrocarbon in the gas stream and hence a measure of its concentration. Such measurements in a wide range of methane concentration and temperature would help to optimize the best experimental conditions to achieve the highest sensitivity. This strategy led to the successful development of a sensor that could monitor up to $4.4 \% \mathrm{CH}_{4}$ in a humid syngas mixture as well as in a humid mixture of $\mathrm{N}_{2} / \mathrm{H}_{2}(50$ vol. $\%$ each). The sensor performed very well over several cycles in the range $500-800^{\circ} \mathrm{C}$. Further refining of the technique made it possible to use a single anode instead of two, thereby simplifying the overall design. Moreover, the chosen composition was stable in methane containing gas streams and showed reversible response over several cycles in a wide temperature range. In this process, some perovskite-structured ceramics (such as Sr-substituted lanthanum chromite, LSCr) were also found to be stable in methane-containing environments. Consequently, galvanic cells using LSCr-based anodes as well responded to various levels of $\mathrm{CH}_{4}$ in humid $\mathrm{N}_{2} / \mathrm{H}_{2}$ and syngas mixtures. The fuel cell based hydrocarbon sensors while showing a response to methane in the presence of low $\mathrm{H}_{2} \mathrm{O}$ partial pressures (2-3\%) where not selective to methane in gas streams of high humidity (28\%). This is believed to be due to the higher $\mathrm{PO}_{2}$ generated as a result of the increased humidity. As a result, in order to utilize an EMF based sensor, it may be necessary to remove the water vapor to adequate levels $(<3 \%)$ to obtain a methane response that is not suppressed by the $\mathrm{PO}_{2}$ generated from $\mathrm{H}_{2} / 28 \% \mathrm{H}_{2} \mathrm{O}$.

\section{Sulfur Sensors}

In the case of hydrogen sulfide, a novel formulation was devised. This consisted of two oxide components: one that could tolerate the reducing environment and exist as a stable phase and the other that could form a sulfide reversibly in the presence of $\mathrm{H}_{2} \mathrm{~S}$ in the gas stream. It is well known that ceria has excellent oxygen storage capacity (OSC). It is able to form oxygen vacancies in oxygen-poor atmospheres and, conversely, to fill these vacancies in oxygen-rich atmospheres. Interestingly, both stoichiometric (oxidized, $\mathrm{CeO}_{2}$ ) and non-stoichiometric (reduced, $\mathrm{CeO}_{2-\mathrm{x}}$ ) are stable over a wide range of temperature and non-stoichiometry. This property of ceria was exploited in developing $\mathrm{H}_{2} \mathrm{~S}$ sensors in the current program. Gadoliniadoped ceria (GDC) was used as the major phase. A number of simple metal oxides were employed as the second phase. The selection was based on a rigorous thermodynamic analysis of the energetics involved in the macroscopic and reversible formation of metal sulfides/oxysulfides from their corresponding oxides in a $\mathrm{H}_{2} / \mathrm{H}_{2} \mathrm{~S}$ mixture. The sensor consisted of these compositions used as thick films in a planar chemiresistor format (films deposited onto alumina substrates with interdigitated gold electrodes printed on them) for monitoring $\mathrm{H}_{2} \mathrm{~S}$ in $\mathrm{H}_{2}$-rich gas stream. In this format, the films responded reversibly to the presence of $\mathrm{H}_{2} \mathrm{~S}$ via a change in the film resistance. The sensors with different chemistries have been tested in the temperature range of $300-550^{\circ} \mathrm{C}$ over several cycles and in backgrounds containing up to $40 \mathrm{vol} \% \mathrm{H}_{2}$.

An assessment of the technical status of material and sensor device development work in Phase I is presented in Table 1. We feel that the technical feasibility of both sensing approaches was established. 


\begin{tabular}{|c|l|l|}
\hline \multicolumn{2}{|c|}{ Table 1. Status of Sensor Technology Development } \\
\hline Sensor & \multicolumn{1}{|c|}{ Development Status (Phase I) } & \multicolumn{1}{c|}{ Additional Work (Phase II) } \\
\hline \multirow{3}{*}{$\mathbf{H C}_{\mathbf{X}}$} & $\begin{array}{l}\text { Galvanic cell mode sensor based on YSZ } \\
\text { electrolyte with novel anode materials } \\
\text { demonstrated for detection of methane } \\
(10 \%) \text { in wet hydrogen ambient. Signals } \\
(\text { OCV) were repeatable over multiple } \\
\text { cycles with no degradation due to coking. }\end{array}$ & $\begin{array}{l}\text { Performance needs to be demonstrated } \\
\text { with real-world gas compositions (i.e., } \\
\text { humid syngas). Ability to detect different } \\
\text { levels of methane needs to be confirmed. } \\
\text { Sensor packaging approaches need to be } \\
\text { developed (i.e., tubular elements). }\end{array}$ \\
\hline $\mathbf{H}_{2} \mathbf{S}$ & $\begin{array}{l}\text { Resistive-mode sensor demonstrated for } \\
\text { detection of 10 ppm } \mathrm{H}_{2} \mathrm{~S} \text { in dry hydrogen } \\
\text { and 1 ppm } \mathrm{H}_{2} \mathrm{~S} \text { in humidified syngas. A } \\
\text { number of sulfur-sensitive materials were } \\
\text { identified for Phase II development and } \\
\text { optimization. }\end{array}$ & $\begin{array}{l}\text { Demonstration of faster response times is } \\
\text { needed (through device miniaturization } \\
\text { and testing methods). Detection of } \mathrm{H}_{2} S \text { in } \\
\text { different baseline syngas compositions } \\
\text { and at higher temperatures needs to be } \\
\text { confirmed. Sensor fabrication methods } \\
\text { need optimization (i.e., screen printing). }\end{array}$ \\
\hline
\end{tabular}

\section{ADDRESSING THE PROBLEM}

In light of the foregoing discussion, the importance of continuous monitoring of gaseous unburned light hydrocarbons (ULHCs) and sulfur $\left(\mathrm{S}_{\mathrm{x}}\right.$ or $\left.\mathrm{H}_{2} \mathrm{~S}\right)$ in SOFC-based power generation systems, cannot be overemphasized. Due to the complex nature of the gas stream, both in the reformate and the fuel cell, and the highly dynamic (and hence non-equilibrium) conditions associated with SOFC operation, it is rather difficult to conceive of a single material or a solitary technique that would address sensing and metering needs throughout the SOFC system. The task becomes even more challenging when one takes into consideration the mitigating conditions under which these sensors are required to operate: high temperatures, high gas velocity, fast changing gas composition and highly reducing (predominantly $\mathrm{H}_{2}$-rich) environments. Therefore, a strategy involving several potential materials and viable technique needs to be employed to meet the requirement of this solicitation for sulfur sensors. In addition, these sensors are required to endure hundreds of thermal cycles and be fail-safe for a service-life of more than 40,000 hours. This calls for the development of reliable and rugged sensors that would be mechanically robust and could withstand the harsh and reducing environment in a wide range of temperature. Reforming is an integral part of SOFC operation, and the proposed sensor system would be of universal relevance irrespective of the fuel type. With these objectives, a program was designed to develop a set of new chemical sensors during Phase I, capable of operating in a variety of fuels streams and at temperatures indigenous to mobile and stationary fuel cells. The information provided by these sensors could be used to suppress, or minimize, the cokeformation attributed to the dissociation of lighter $\mathrm{HCs}$ (on the anode) by varying the $\mathrm{O}_{2}$ or $\mathrm{H}_{2} \mathrm{O}$ content in the reforming process. Similarly, the use of sulfur sensors before and after the 
desulfurizer unit would help in quantifying its efficiency. However, development of these sensors, pose a serious materials challenge.

While the field of chemical gas sensor development is broad, as evidenced by an ever-increasing number of technical papers and patents, sensors for real-world applications are practically nonexistent. For example, a majority of chemical sensors are low temperature devices and suffer from long response times, lack of selectivity, degradation of signal over time and storage, and need oxygen to operate [1]. A thorough and exhaustive survey of the open literature and the commercial market has shown that a sensor capable of monitoring and/or metering hydrocarbons and hydrogen sulfide in $\mathrm{H}_{2}$-containing background does not exist. There are, however, a number of hydrogen sulfide detectors reported in the literature and also available commercially for air quality monitoring purposes. They are predominantly based on the familiar tin oxide (Figaro and Taguchi) technology with one or more minor additives (such as $\mathrm{Au}, \mathrm{Pd}, \mathrm{CuO}, \mathrm{NiO}$, etc.). These sensors work on the principle of change in film resistance upon exposure to $\mathrm{H}_{2} \mathrm{~S}$ in air over a limited range of temperatures and concentrations. The non-specificity is a major issue with these devices. The alarm sounds off even when a volatile species such as alcohol is in its vicinity. The suggested use of commercial sulfur detectors is only in air [2-8]. Devices based on optical flame photometry or chemiluminescence are tedious, intrusive and expensive in addition to being capable of detecting sulfur in solution only [9]. Other detectors for $\mathrm{H}_{2} \mathrm{~S}$ include surface acoustic wave or SAW device ( $\mathrm{Au}$ doped- $\left.\mathrm{WO}_{3}\right)$, MOS device $\left(\mathrm{Pd}\left|\mathrm{SiO}_{2}\right| \mathrm{Si}\right), \mathrm{SnO}_{2}|\mathrm{CuO}| \mathrm{SnO}_{2}$ currentvoltage (I-V) device and electrochemical sensors (the EMF changes when $\mathrm{H}_{2} \mathrm{~S}$ is adsorbed on $\mathrm{PbS}$ surface or when it encounters a sulfuric acid-soaked Nafion film) [10-15]. Again, the temperature and concentration range of these techniques are quite low and they too operate in ambient air. Likewise, with the exception of a $\mathrm{CH}_{4}$ sensor based on $\mathrm{SiC}$ wafers and working on current-voltage mode [16-17], majority of hydrocarbon sensors require the presence of oxygen to be operational [18-21].

The basic mechanism of operation of sensors based on semiconducting oxides is fairly well understood. For example, tin oxide is considered to be an n-type semiconductor, and the sensing behavior of n-type semiconductors appear to be governed by the adsorption of oxygen in the neck regions between the grains. Adsorption of oxygen from the ambient increases the resistance of the film due to extraction of electrons from the conduction band. This leads to the depletion of electrons and creation of a space charge region near the surface. Eventually a steady-state condition is achieved and the charge transfer to adsorbed oxygen is impeded due to the electrostatic field at the surface. In the presence of a reducing gas (which reacts with the adsorbed charged oxygen species on the surface), there is a donation of electrons to the conduction band and the conductivity is seen to increase [22]. This is schematically shown in Fig. 1, with $\mathrm{CO}$ as an example. 


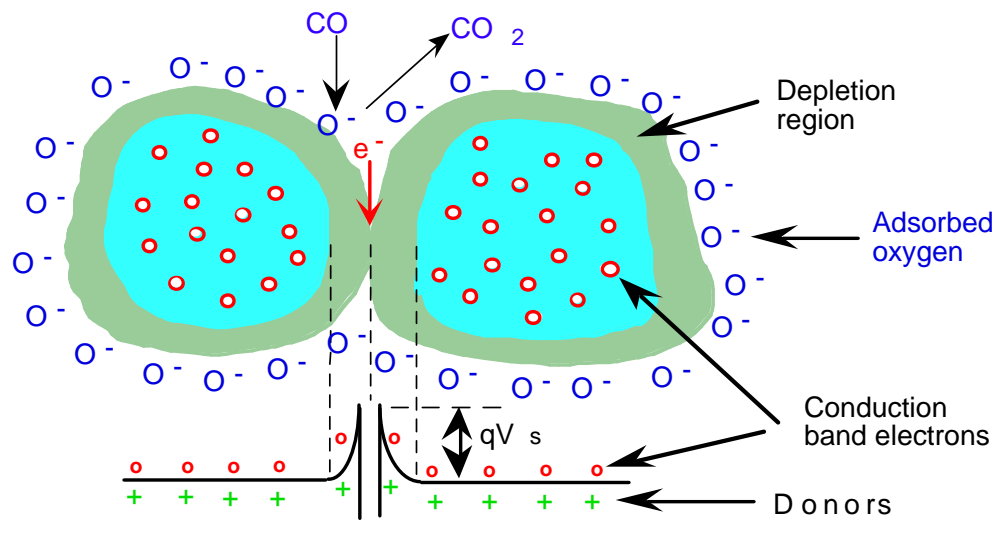

Fig. 1. Sensing model of a semiconducting material showing the depletion region and energy barrier $\left(\mathrm{qV}_{\mathrm{s}}\right)$ at the intergranular contact.

However, as outlined above, the working principle of resistive-type sensors relies heavily on the assumption of the presence of oxygen in the ambient. In the case of reformate feed the gas stream is $\mathrm{H}_{2}$-rich. $\mathrm{H}_{2}$ being more reducing in nature and present in much larger concentration than other reducing species of interest, it will have much greater affinity towards the adsorbed oxygen species. As a matter of fact, the threshold detection limit for $\mathrm{CO}$ in a PEMFC anode gas stream is less than $40 \mathrm{ppm}$ and that of sulfur (in the form of $\mathrm{H}_{2} \mathrm{~S}$ ) in PEMFC and SOFC both is less than $1 \mathrm{ppm}$. Consequently, the presence of the latter is likely to be totally masked. Therefore, it is difficult to develop a sensor for reducing gases in $\mathrm{H}_{2}$-rich reformate. Moreover, some semiconducting oxide films used for sensing purposes would be readily reduced to its suboxide or corresponding metal, by hydrogen in the anode stream, prior to showing any response to the minor constituents of interest.

Hence, the sensing mechanism based on oxygen adsorption becomes invalid. Moreover, detecting and metering small concentrations (10-100s of ppm) of reducing species such as CO, $\mathrm{HCs}$ or $\mathrm{H}_{2} \mathrm{~S}$ in the presence of several 10 s of percent of hydrogen by resistive approach, becomes quite challenging.

\section{EXPERIMENTAL}

\section{Fabrication of Hydrocarbon Sensors}

In the case of methane sensors, hydrothermally synthesized, calcined and thoroughly characterized YSZ and/or GDC powders were thoroughly mixed with $\mathrm{NiO}$ or $\mathrm{CuO}$ in adequate proportions so as to get $45-50$ vol. $\%$ of metal oxide in the composite. The mixtures were ball milled in isopropanol for 8 hours, dried and made into homogenous viscous slurry by mixing with an organic vehicle and terpineol, so as to give about $70 \%$ solid loading in the resulting ink. These inks were used to form the anode films in the fuel cell mode sensors. The inks were painted onto one side of dense $\mathrm{YSZ}$ discs and slowly fired in air at $900^{\circ} \mathrm{C}$ (for $\mathrm{CuO}$ composites) and $1350^{\circ} \mathrm{C}$ (for $\mathrm{NiO}$ composites) for 1 hour, so as to form an adherent film. In the case of $\mathrm{LSCr}$, the ink was made similarly and the film was fired at $950^{\circ} \mathrm{C}$ for 1 hour. Commercial platinum paste (Engelhard, NJ) was applied on the opposite surface of the $\mathrm{YSZ}$ disc and fired at $850^{\circ} \mathrm{C}$ for 
30 minutes. This left a porous Pt film forming the airside cathode. Silver wires were attached to both the electrodes with Heraeus silver paste by first curing at $\sim 100^{\circ} \mathrm{C}$ for few minutes followed by firing at $\sim 300^{\circ} \mathrm{C}$ for 30 minutes in air.

The sensor was finally sealed to an open-ended alumina tube with an aqueous base Aremco sealant, with Pt cathode exposed to air. The other end was designed to accommodate the inlet and outlet for the gas mixture. The schematic of the methane sensor is shown in Fig. 2.

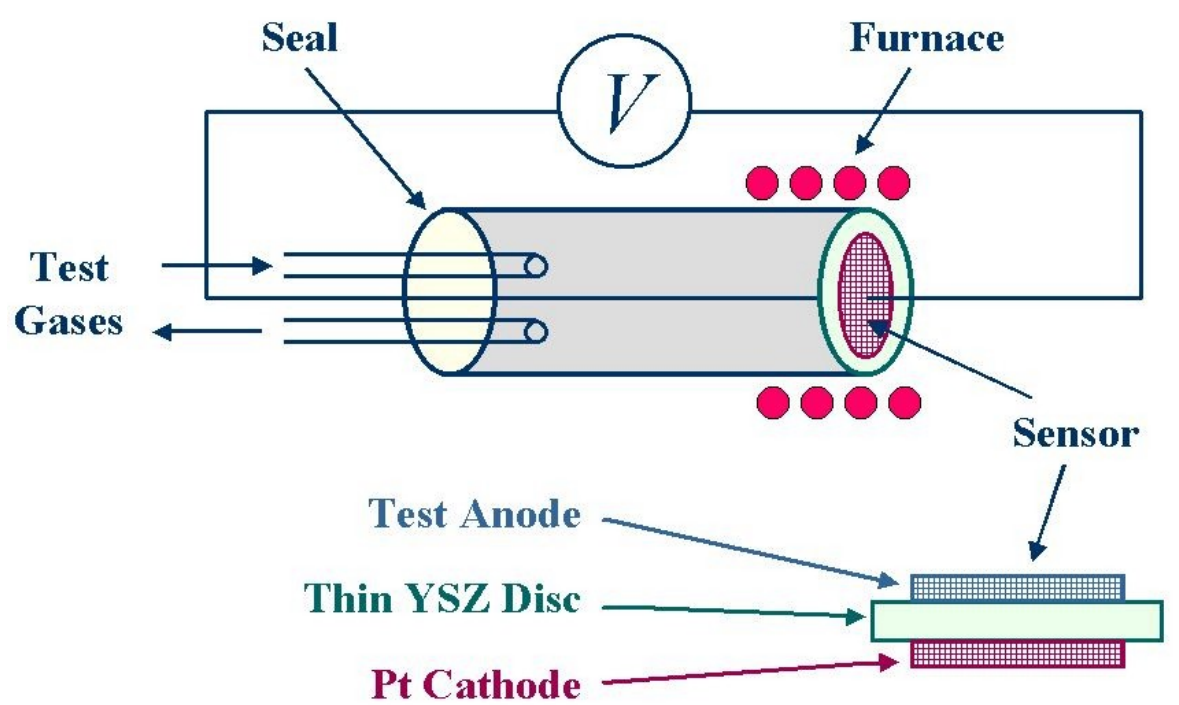

Fig. 2. NexTech "Fuel Cell" hydrocarbon sensor design.

\section{Fabrication of Hydrogen Sulfide Sensors}

In the case of sulfur sensors, nanoscale GDC powders were thoroughly mixed with 1-10 wt.\% $\mathrm{MoO}_{3}, \mathrm{WO}_{3}, \mathrm{TiO}_{2}, \mathrm{SnO}_{2}, \mathrm{Sb}_{2} \mathrm{O}_{3}$ and converted into inks as described above. In some cases a third insulative phase $\left(\mathrm{Al}_{2} \mathrm{O}_{3}\right)$ was added to increase the baseline resistance at high temperature. The sensor consisted of these compositions painted as thick films in a planar chemiresistor format (films deposited onto alumina substrates with interdigitated gold electrodes printed on them; Fig. 3) and fired at appropriate temperatures in the range of $600-900^{\circ} \mathrm{C}$ for 1 hour. 


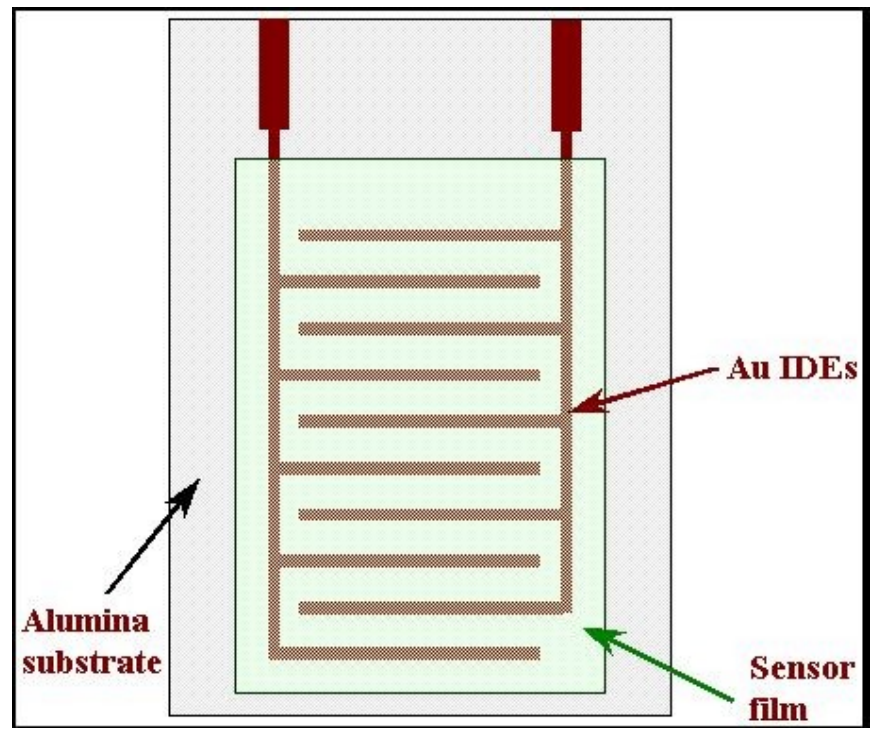

Fig. 3. Schematic of a chemi-resistive sensor on an alumina substrate with Au-electrodes.

\section{Sensor Characterization}

The test stand shown in Fig. 4 was used for testing sensors for methane and $\mathrm{H}_{2} \mathrm{~S}$. Since $\mathrm{H}_{2} \mathrm{~S}$ is a poisonous and toxic gas, great care was taken to establish a protocol for its safe handling, delivery and disposal. The simulated gas mixtures were produced from standard compressed gas cylinders containing various levels of methane or $\mathrm{H}_{2} \mathrm{~S}$ in adequately humid $\mathrm{H}_{2}, \mathrm{CO}, \mathrm{CO}_{2}$ in $\mathrm{N}_{2}$ background by bleeding proper flows of various gases through Sierra mass flow controllers (MFCs), which in turn were controlled by a Sierra Control Box. In order to generate a moist environment, the mixture was passed through a water bath (or suitable saturated salt solution) to create a desired level of humidity. The sensor was located in the uniform temperature zone of a compact low-mass furnace that was heated to the desired temperature at which measurements are sought. In the case of sulfur sensor development, the exhaust stream from the test capsule was passed through reagent bottles containing aqueous solutions of lead acetate and silver nitrate (100 $\mathrm{mM}$ strength), before it was discharged to the atmosphere through a fume hood. The $\mathrm{H}_{2} \mathrm{~S}$ in the gaseous stream was quantitatively stripped by these two reagents to form either lead or silver sulfide.

An Agilent 34401A digital multimeter connected via serial port to a desktop computer for controlled data acquisition was utilized to make electrical measurements. The sensor was heated to a given temperature and steady-state resistance (sulfur sensor) or open circuit voltage (methane sensor) was measured both as a function of temperature as well as the level of HC or $\mathrm{H}_{2} \mathrm{~S}$ in the stream. In this work, we could vary $\mathrm{CH}_{4}$ concentration between 3.6 to 15 vol.\%, though most of the measurements have been carried out at $4.4 \%$ level. In the case of sulfur sensors, measurements have been carried out at 1 and $10 \mathrm{ppm}_{2} \mathrm{~S}$ levels in a background containing 10-40\% $\mathrm{H}_{2}$. The reversibility of the sensor behavior was verified both as a function of gas composition and temperature. The response time $\left(t_{90}\right)$ as well the time taken to return to the baseline in each case were estimated. 


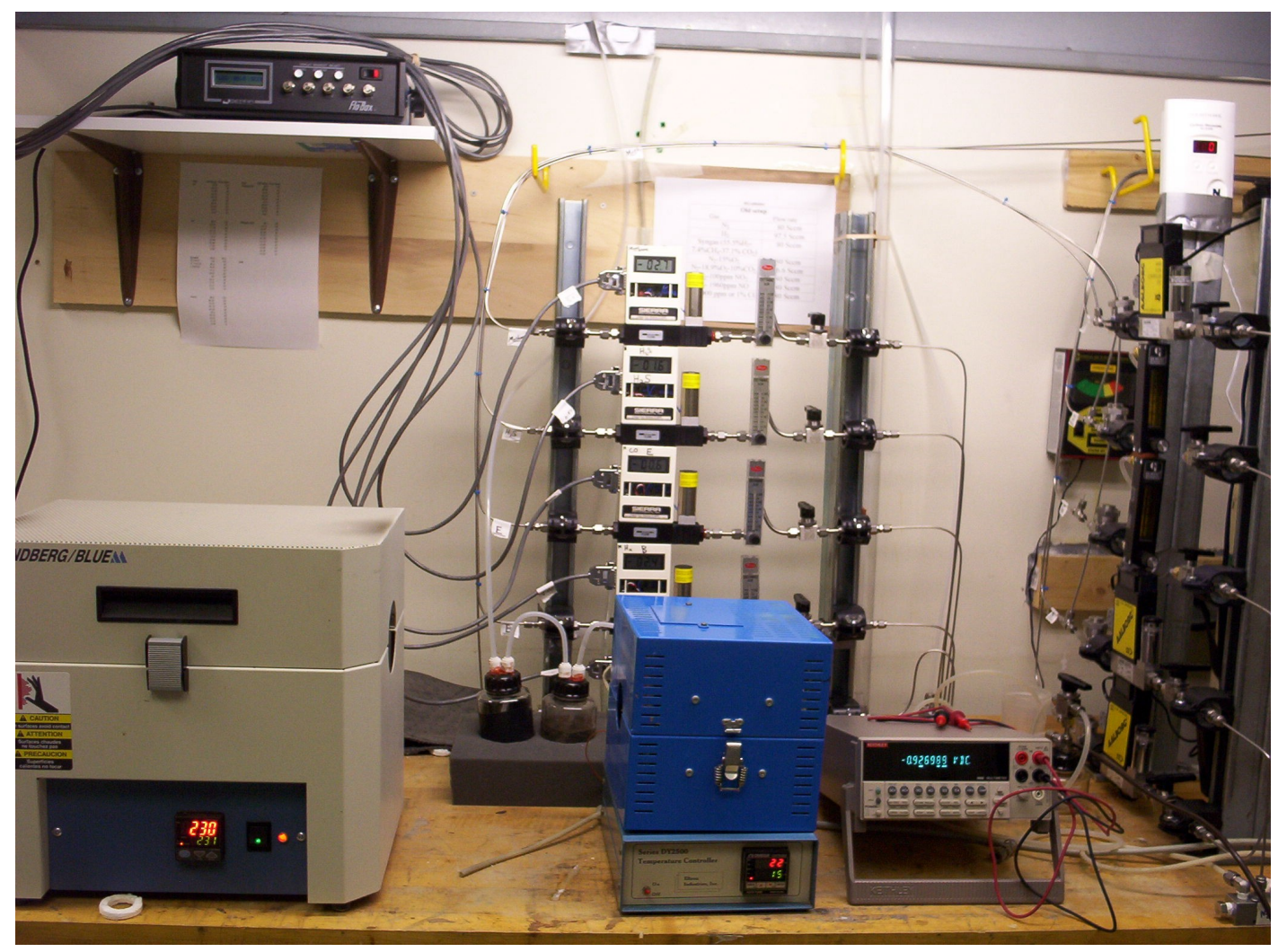

Fig. 4. Assembly of a bench-top gas sensing apparatus.

\section{RESULTS AND DISCUSSION}

\section{Hydrocarbon Sensors}

The response of a fuel cell sensor with Ni/YSZ as the sensing anode (no load condition) to the presence of $4.4 \%$ methane at 600 and $700^{\circ} \mathrm{C}$ is shown in Fig. 5. It can be seen that the OCV of the cell is quite high and near theoretical in $\sim 49 \% \mathrm{~N}_{2} / 49 \% \mathrm{H}_{2} / 2 \% \mathrm{H}_{2} \mathrm{O}$ mixture. It is also interesting to note that the signal (decrease in $\mathrm{OCV}$ ) is large and very consistent over several cycles; there is no sign of deactivation at $600^{\circ} \mathrm{C}$. However, the deactivation of the anode sets in at $700^{\circ} \mathrm{C}$, indicated by the drop in OCV as well as the inability of the cell to respond to methane reversibly. We ascribe this to the coke-formation on the anode at this temperature. The severity of the problem is accentuated at even higher temperatures, as seen from Fig. 6. 


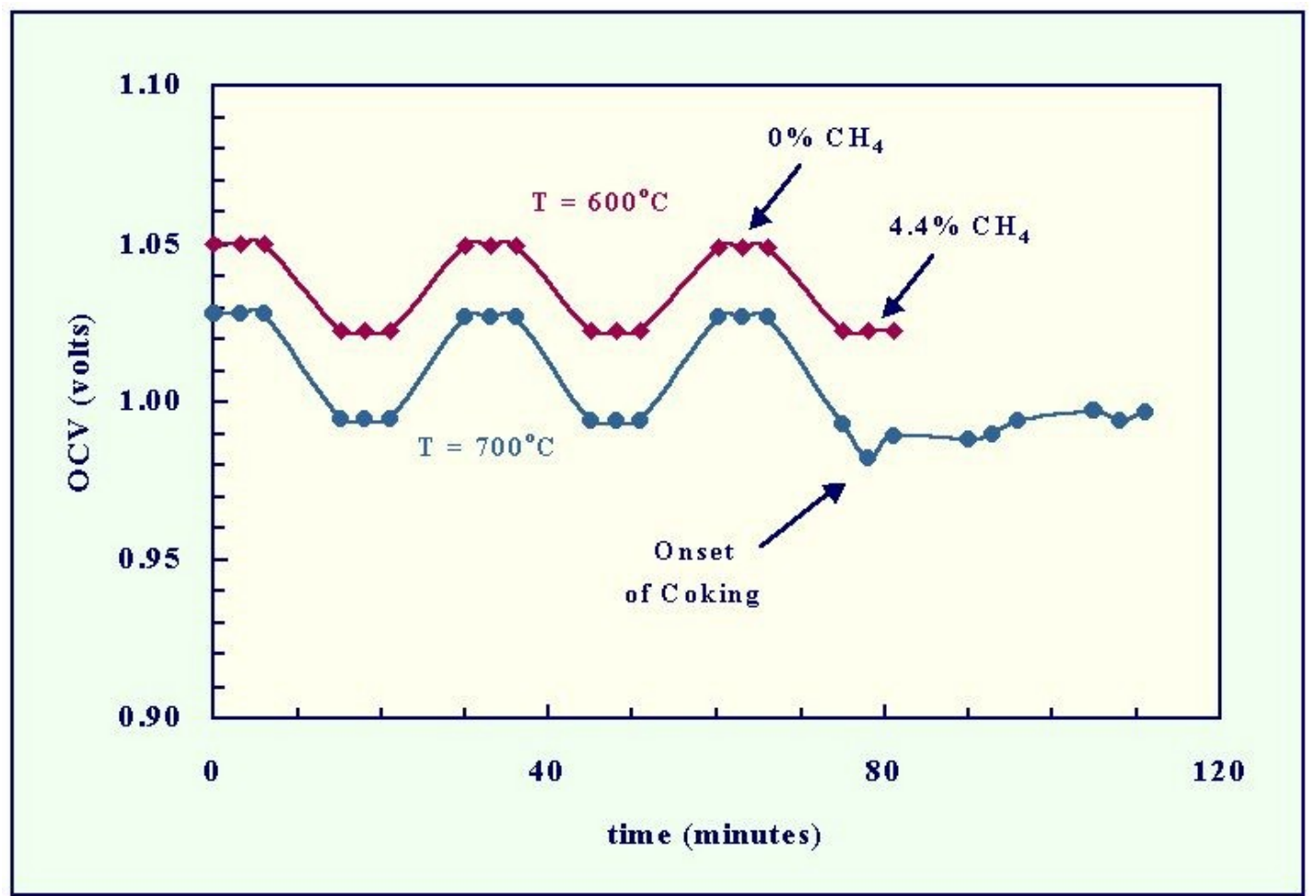

Fig. 5. Sensitivity of a Ni/YSZ anode-based fuel cell sensor to $4.4 \% \mathrm{CH}_{4}$.

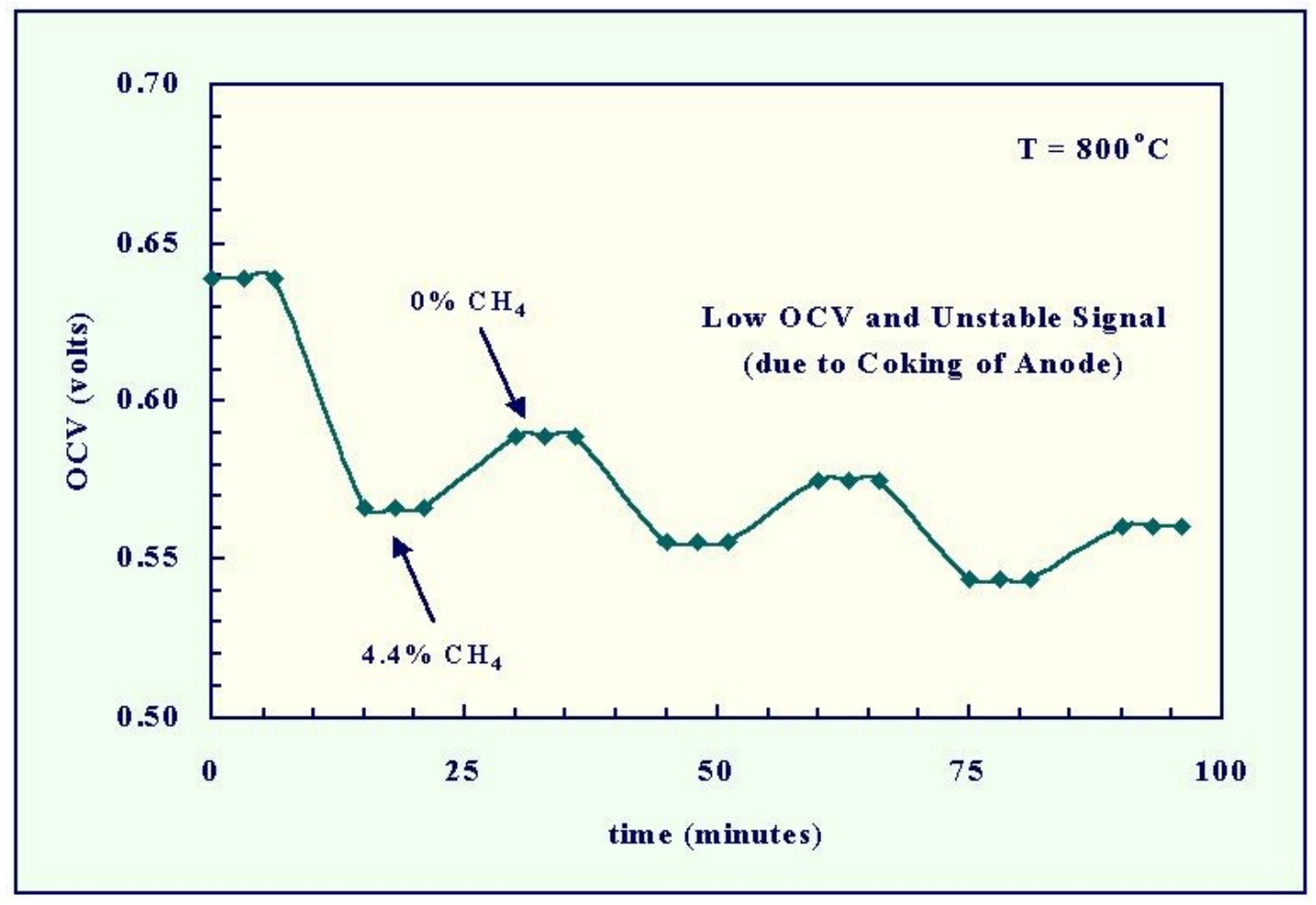

Fig. 6. Enhanced rate of deactivation of the $\mathrm{Ni} / \mathrm{YSZ}$ anode at $800^{\circ} \mathrm{C}$. 
On the contrary, the Ni/GDC anodes performed excellently over several cycles without showing any sign of deactivation by way of coke formation and carbon deposition up to $800^{\circ} \mathrm{C}$ (Fig. 7). This again could be attributed to the unique ability of cerium oxide to exist in a stable form both in an oxidizing as well as a reducing environment.

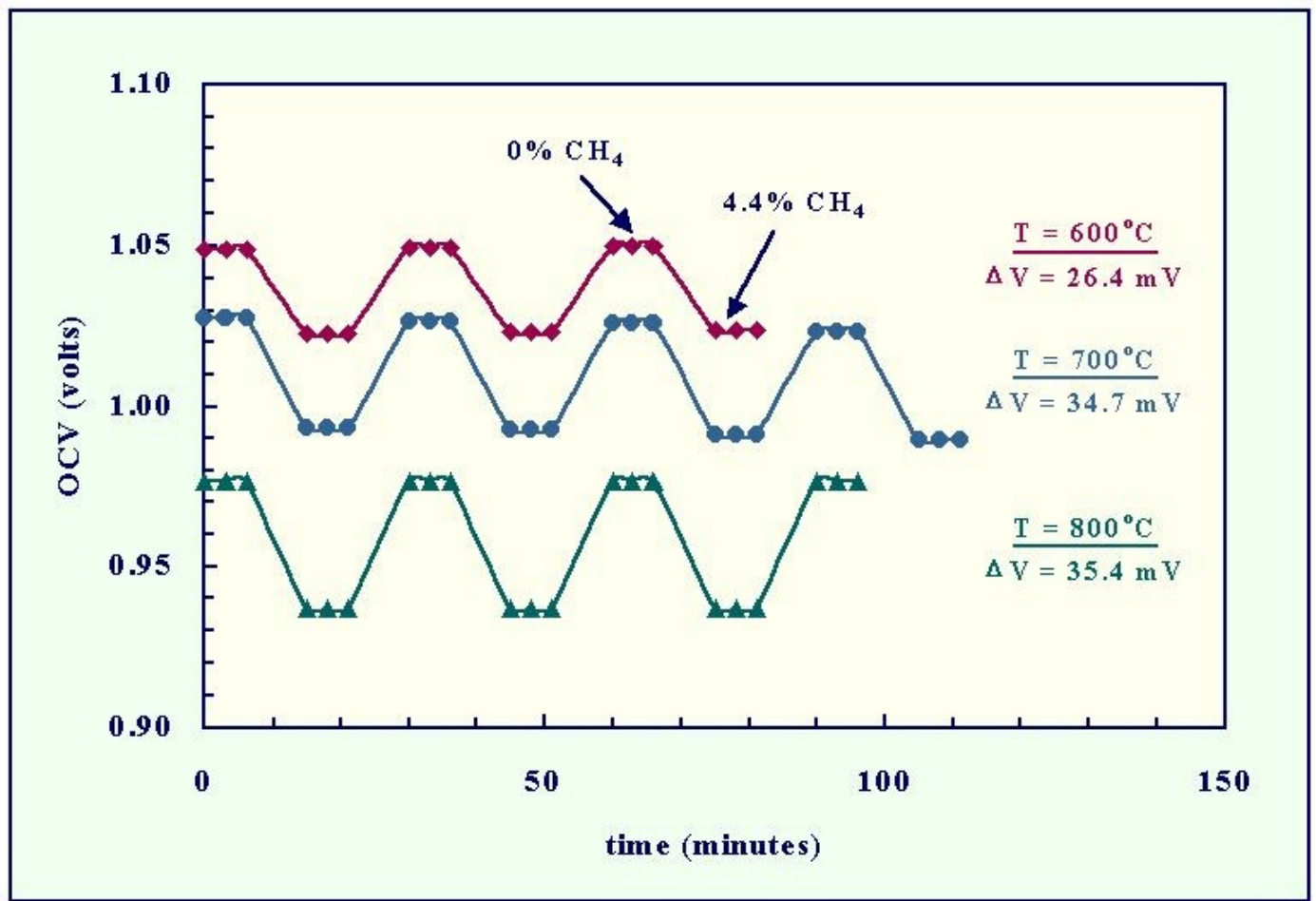

Fig. 7. Stable performance of Ni/GDC anode towards $\mathrm{CH}_{4}$ in syngas up to $800^{\circ} \mathrm{C}$.

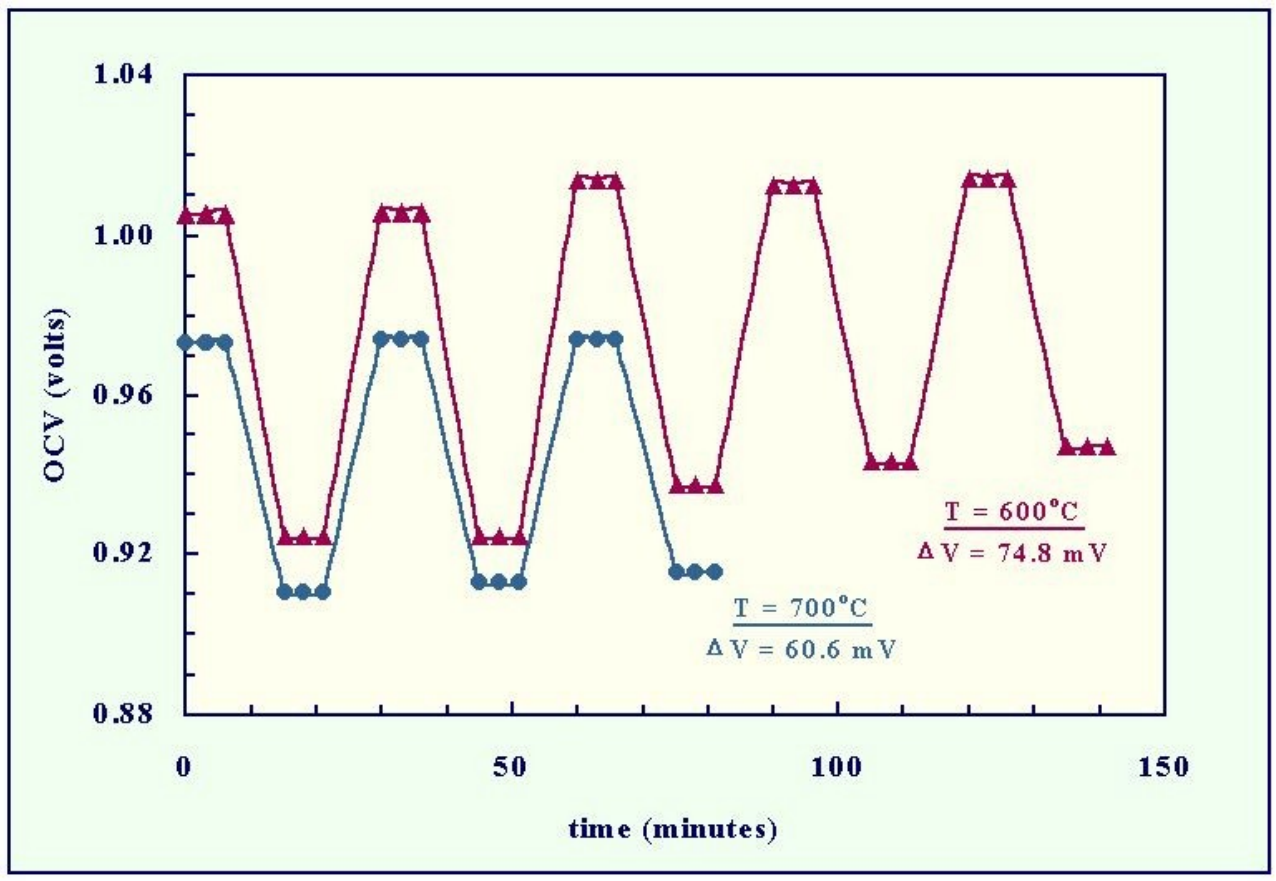

Fig. 8. Response of $\mathrm{CuO} / \mathrm{GDC}$ anode in the presence of $3.6 \% \mathrm{CH}_{4}$ in reformate. 
Sensitivity twice as high as that of Ni-bearing anodes was obtained with composites of GDC with $\mathrm{Cu}$, at corresponding temperatures. A typical response of a $\mathrm{CuO} / \mathrm{GDC}$ anode in the presence of $3.6 \%$ methane in a simulated reformate gas stream at 600 and $700^{\circ} \mathrm{C}$, is shown in Fig. 8. In particular, this formulation showed no evidence of coke-formation or deactivation.

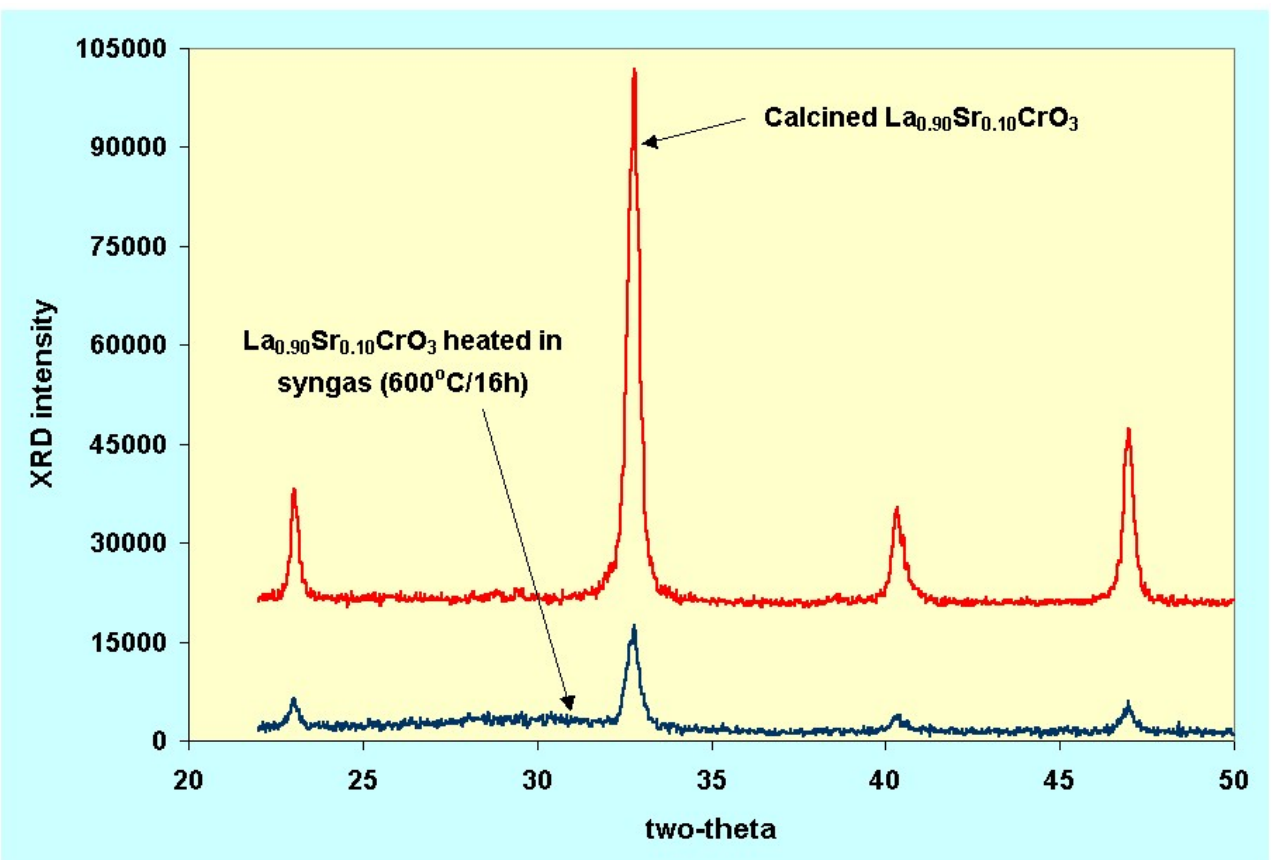

Fig. 9. Phase stability of $\mathrm{La}_{0.90} \mathrm{Sr}_{0.10} \mathrm{CrO}_{3}$ during long-term reaction studies in syngas.

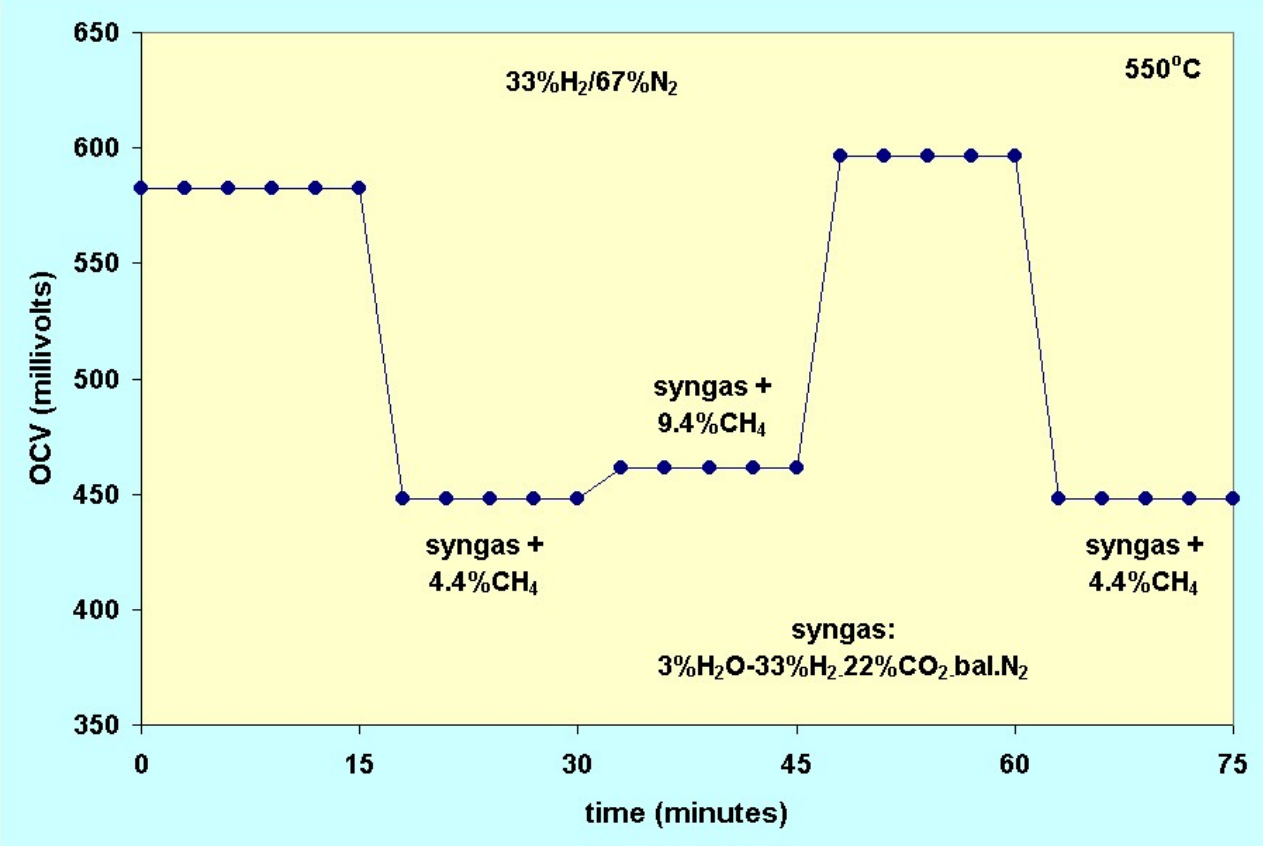

Fig. 10. Response of $\mathrm{Sr}$-substituted $\mathrm{LaCrO}_{3}$ anode film to $4-10 \% \mathrm{CH}_{4}$ at $550^{\circ} \mathrm{C}$. 
It should be pointed out that though the $\mathrm{Sr}$-doped $\mathrm{LaCrO}_{3}$ anode did not yield an $\mathrm{OCV}$ similar to $\mathrm{Ni} / \mathrm{GDC}$ or $\mathrm{Cu} / \mathrm{GDC}$ (near theoretical), it did not degrade in a syngas stream during a simulation study (Fig. 9) and performed well in detecting methane in the concentration range of 4.4-10\%, in fuel cell mode in the range 550 to $800^{\circ} \mathrm{C}$. A typical response of a lanthanum chromite-based fuel cell sensor at $550^{\circ} \mathrm{C}$ is shown in Fig. 10. When attempting to measure methane in the presence of $28 \% \mathrm{H}_{2} \mathrm{O} / \mathrm{H}_{2}$ atmospheres (typical of the reformate at the SOFC anode), no response to $\mathrm{CH} 4$ was noted. This can be explained when evaluating the $\mathrm{PO}_{2}$ equilibrium difference established between the two theorized reactions. During methane sensing, NexTech believes that reversible carbon deposition is the dominant mechanism based on the following reaction.

$$
\mathrm{CH}_{4}+\mathrm{O}_{2} \rightarrow \mathrm{C}+2 \mathrm{H}_{2} \mathrm{O}
$$

When evaluating the Gibbs energy associated with this reaction, a corresponding voltage can be calculated based on $\Delta \mathrm{G}=-\mathrm{nFE}$, where $\mathrm{n}$ is the number of moles of electrons per mole of reaction and $\mathrm{F}$ is Faraday's constant. To calculate the associated oxygen partial pressure, the Nernst equation for an air reference electrode is used:

$$
\mathrm{PO}_{2}=0.209 \mathrm{e}^{(-46.421 \mathrm{E} / \mathrm{T})}
$$

For the reaction in (1), with methane of $4 \%$ an oxygen partial pressure of $1.54 \times 10^{-25}$ atm and $1.65 \times 10^{-21} \mathrm{~atm}$, are calculated at 600 and $800^{\circ} \mathrm{C}$, respectively. For the $\mathrm{H}_{2} / \mathrm{H}_{2} \mathrm{O}$ at $28 \%$ a $\mathrm{PO}_{2}$ of $3.06 \times 10^{-25}$ and $1.14 \times 10^{-19}$ are calculated at 600 and $800^{\circ} \mathrm{C}$, respectively. Thus, the $\mathrm{PO}_{2}$ established at the higher water content dominants at all temperatures where this device would be used. As a result, in order to utilize an EMF based sensor, it may be necessary to remove the water vapor to adequate levels $(<3 \%)$ to obtain a methane response that is not suppressed by the $\mathrm{PO}_{2}$ generated from $\mathrm{H}_{2} / 28 \% \mathrm{H}_{2} \mathrm{O}$ equilibrium. Because of these issues, the final two months of the program were focused the hydrogen sulfide sensor development.

\section{Hydrogen Sulfide Sensors}

The sensor consisted of thick films in a planar chemiresistor format (films deposited onto alumina substrates with interdigitated gold electrodes printed on them) for monitoring $\mathrm{H}_{2} \mathrm{~S}_{\text {in }} \mathrm{H}_{2-}$ rich gas stream. In this format, the films responded reversibly to the presence of $\mathrm{H}_{2} \mathrm{~S}$ via a change in the film resistance. Figures 11 through 13 show the response of a single 5-wt\% $\mathrm{MoO}_{3^{-}}$ GDC film to $10 \mathrm{ppm} \mathrm{H}_{2} \mathrm{~S}$ in a $\mathrm{N}_{2} / \mathrm{H}_{2}$ background. This sensor has been tested for 120 uninterrupted hours at various temperatures in the range $295-500^{\circ} \mathrm{C}$ without deterioration. 
Phase I Final Report

DOE Contract No. DE-FC26-02NT41576

November 18, 2003

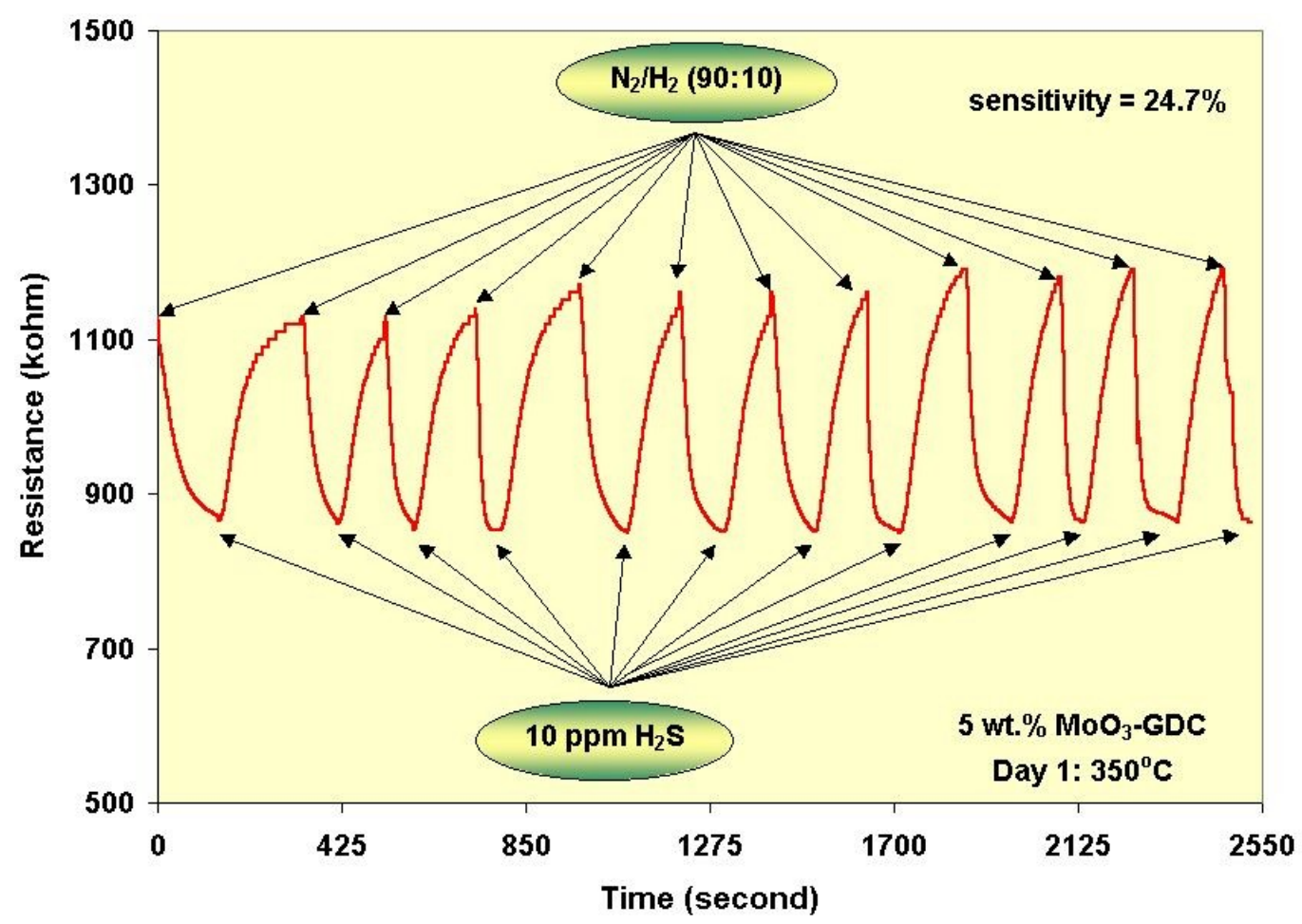

Fig. 11. Response at $350^{\circ} \mathrm{C}$ (12 successive repeatable cycles).

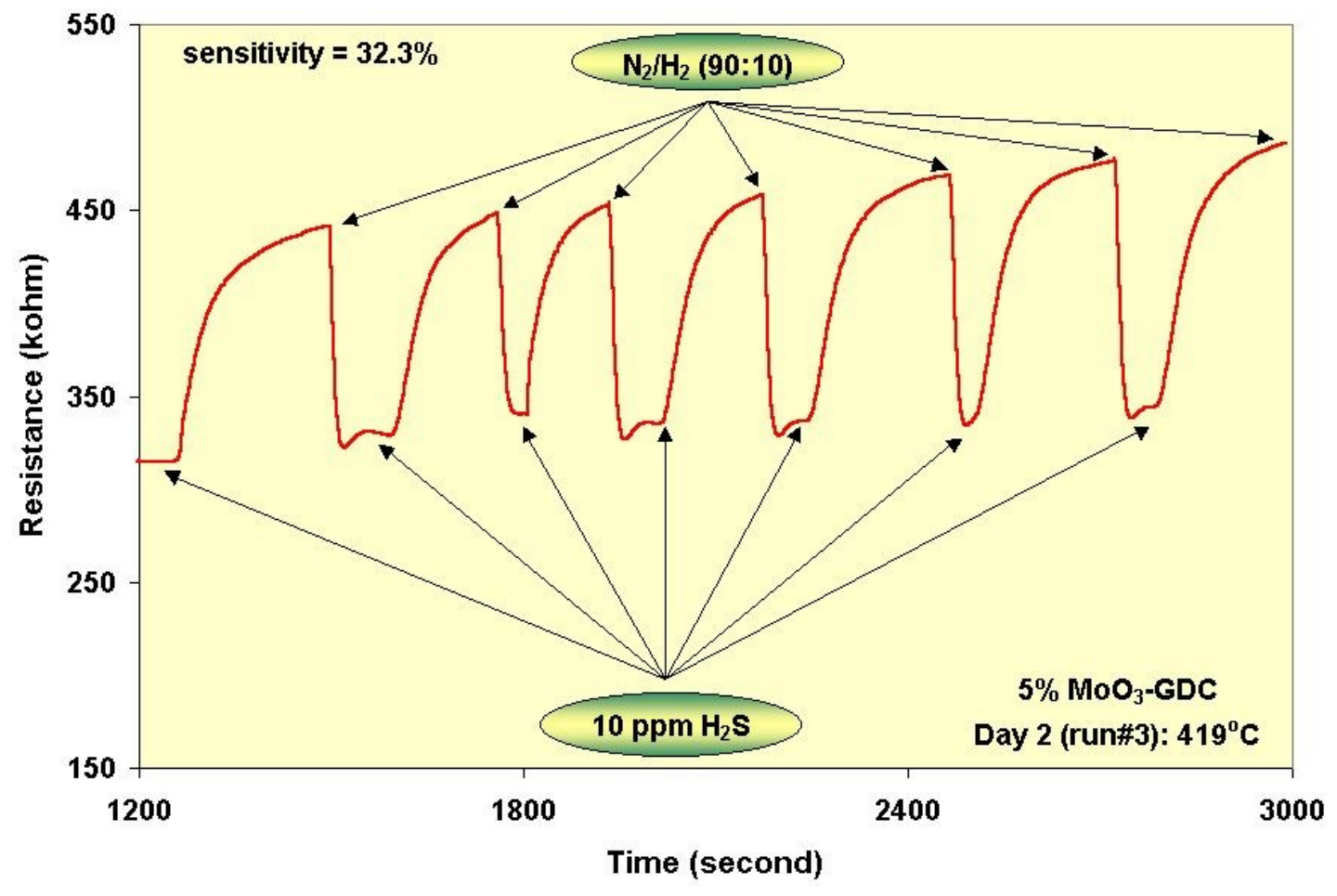

Fig. 12. Repeatable response of the sensor at $\sim 420^{\circ} \mathrm{C}$. 


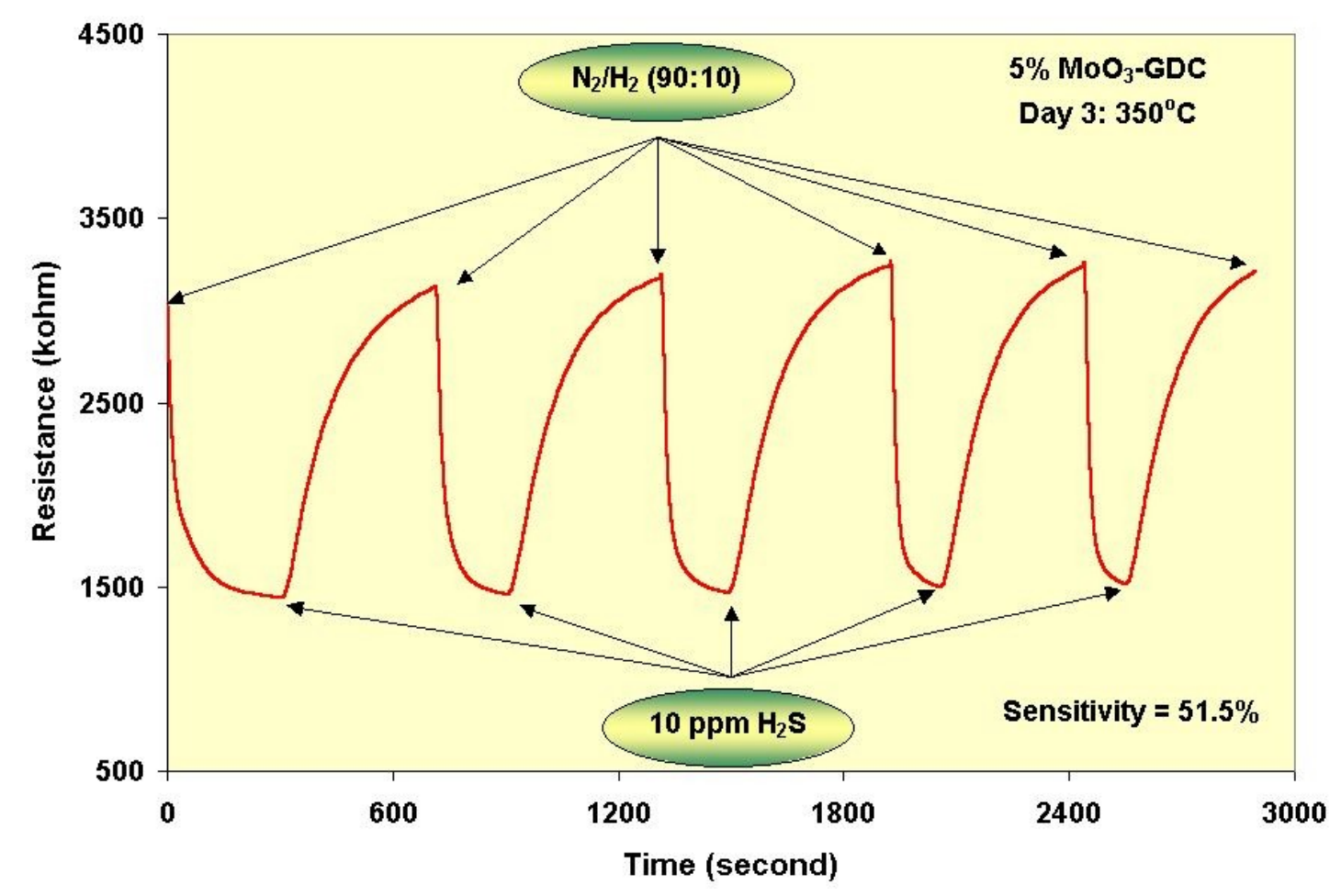

Fig. 13. Response of $5 \% \mathrm{MoO}_{3}-\mathrm{GDC}$ film on day 3 at $350^{\circ} \mathrm{C}$.

Several interesting features of the sensor can be highlighted:

1. The sensor formulation responds to $\mathrm{H}_{2} \mathrm{~S}$ in a gas stream containing $10 \mathrm{vol} \% \mathrm{H}_{2}$.

2. The sensor is reversible and the signal does not fade or dampen upon cycling during a given run or between several runs.

3. The sensitivity $\left(=\frac{R_{b}-R_{g}}{R_{b}}\right)$ is quite appreciable.

4. The response is linear with respect to temperature: higher at low temperatures and less pronounced at high temperatures. This is in tune with many resistive-type sensors whose sensitivity declines sharply with increase in temperatures, due to enhanced rate of desorption of the gaseous species of interest.

5. Upon aging, the response of the sensor at a given temperature, improves appreciably.

6. The response time $\left(t_{90}\right)$ and the time of recovery calculated from the magnitude of the signals were estimated to be about $15 \mathrm{~s}$ and $150 \mathrm{~s}$, respectively.

Composites of GDC with second phase $\left(\mathrm{MoO}_{3}, \mathrm{WO}_{3}, \mathrm{TiO}_{2}, \mathrm{Sb}_{2} \mathrm{O}_{3}\right.$, etc.) ranging between 1-10 wt.\% have also shown response to $10 \mathrm{ppm}$ of $\mathrm{H}_{2} \mathrm{~S}$ in $\mathrm{N}_{2} / \mathrm{H}_{2}$ mixtures. A typical response of $\mathrm{WO}_{3}$ GDC thick film sensor is shown in Fig. 14. 
Phase I Final Report

DOE Contract No. DE-FC26-02NT41576

November 18, 2003

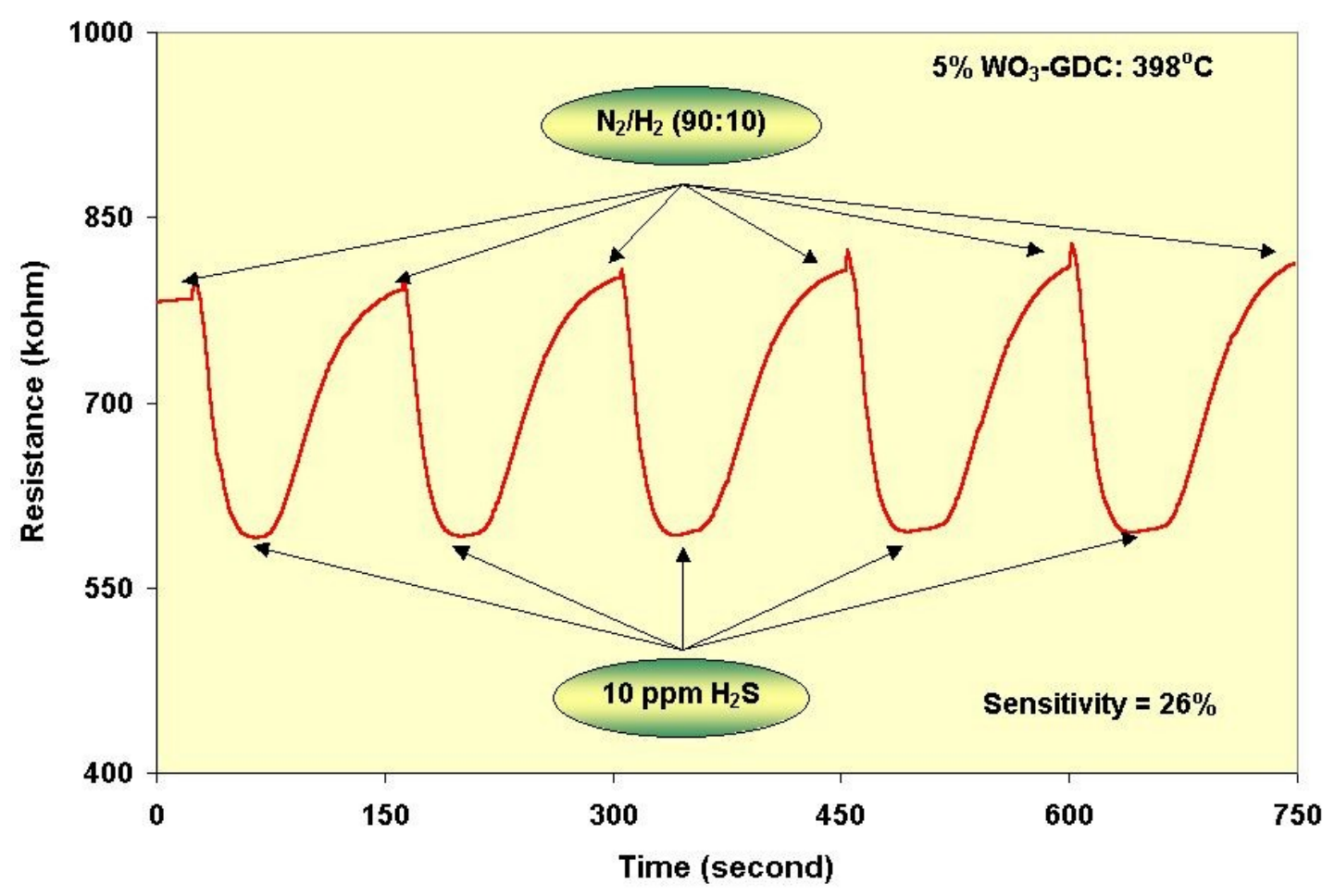

Fig. 14. Response of a $5 \% \mathrm{WO}_{3}-\mathrm{GDC}$ film at $400^{\circ} \mathrm{C}$.

Limited number of tests has also been conducted on sensors made with two-phase composite formulations in backgrounds containing $20-25 \%\left(\mathrm{H}_{2}\right)$ - balance $\left(\mathrm{N}_{2}\right)$.

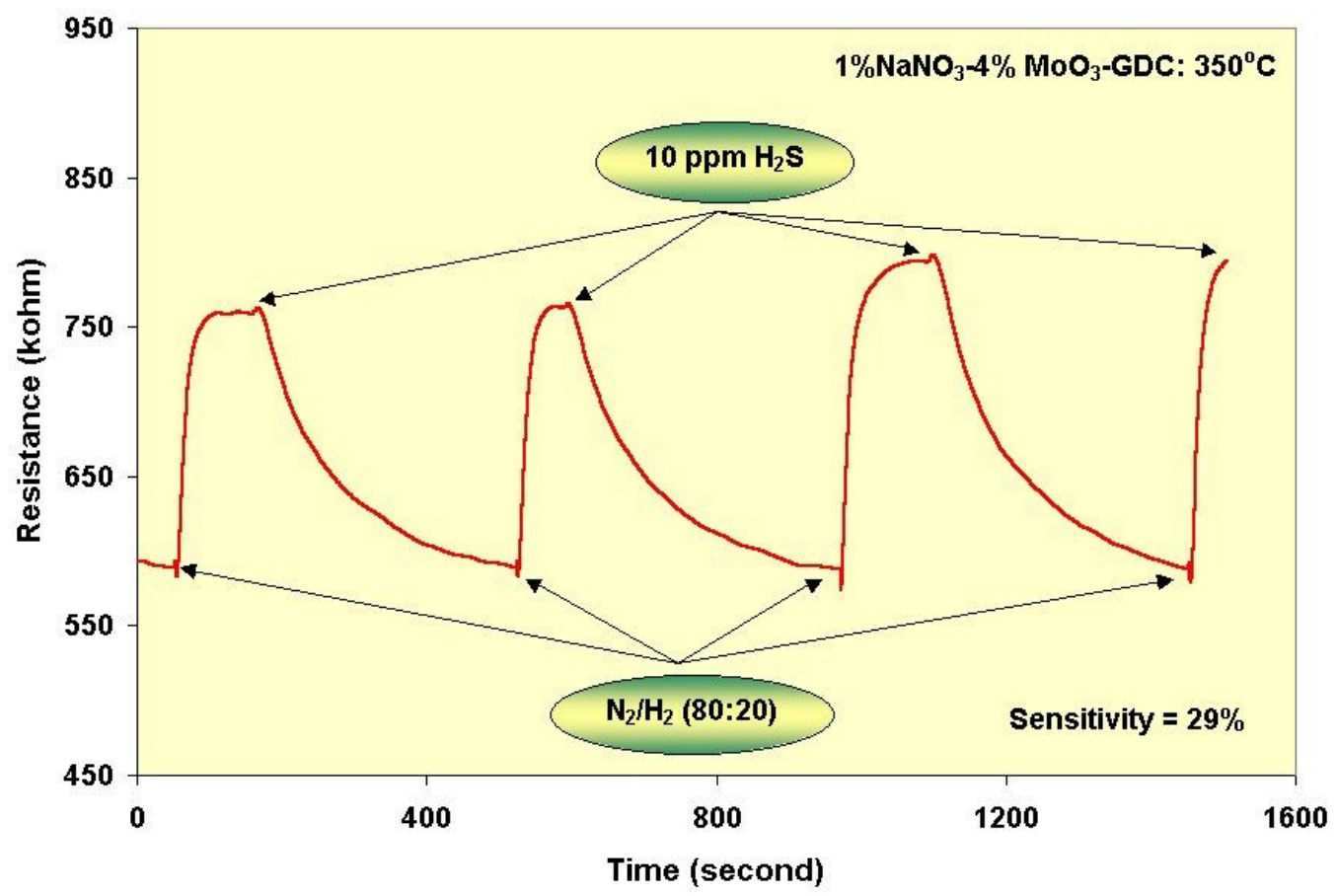

Fig. 15. Response of Na-catalyzed $\mathrm{MoO}_{3}$-GDC to 10 ppm $\mathrm{H}_{2} \mathrm{~S}$ in $20 \% \mathrm{H}_{2}$ background. 


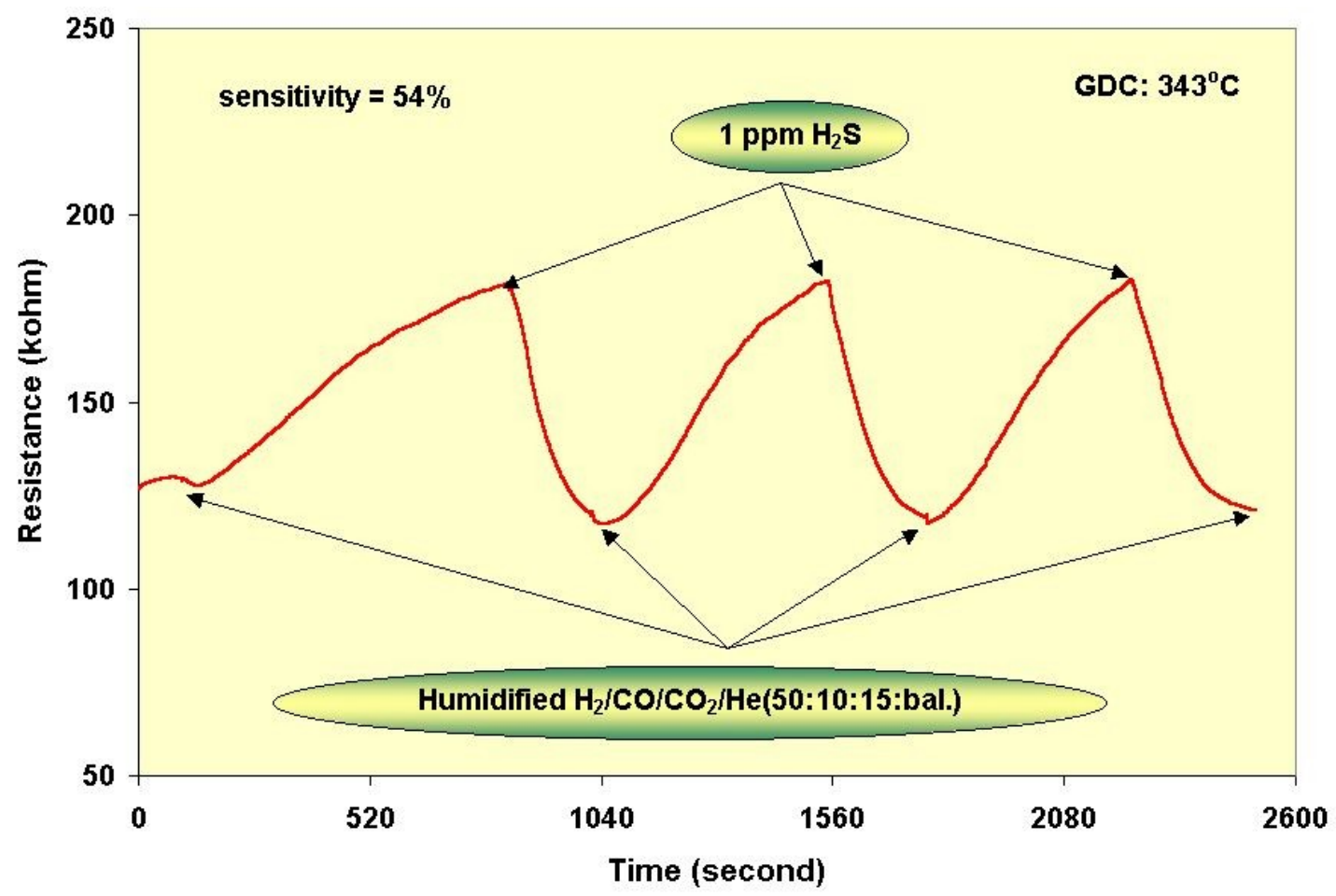

Fig. 16. Response of a GDC film to $1 \mathrm{ppm}_{2} \mathrm{~S}$ in a simulated syngas stream.

As seen from Figs. 15 and 16, there is a reversal of the direction of response (from decrease in the film resistance in $10 \% \mathrm{H}_{2}$ background, to increase in streams with higher concentration of $\mathrm{H}_{2}$ ). Evidently, this is related to the change in the mode of conduction in the material under investigation, as the ambient is made more reducing. After testing several initial samples of GDC combined with various weight percentages of $\mathrm{MoO}_{3}, \mathrm{WO}_{3}, \mathrm{TiO}_{2}, \mathrm{SnO}_{2}$, and $\mathrm{Sb}_{2} \mathrm{O}_{3}$ on the chemiresistors, it quickly became apparent that the best response was yielded with the composition using GDC and $\mathrm{MoO}_{3}$. Additionally, it was realized that the baseline resistance was too low to see a strong response to the sulfur at higher temperatures, $\sim 500{ }^{\circ} \mathrm{C}$ and above. To increase this baseline resistance to a value where the response could be better quantified a third phase would need to be added to the GDC and $\mathrm{MoO}_{3}$ inks. Alumina $\left(\mathrm{Al}_{2} \mathrm{O}_{3}\right)$ appeared to be an ideal candidate because of its insulative nature. Using a base composition of $10 \mathrm{wt} . \% \mathrm{Al}_{2} \mathrm{O}_{3}, 5$ wt. $\% \mathrm{MoO}_{3}$, and $85 \mathrm{wt} . \% \mathrm{GDC}$, a test matrix for characterizing the response to $\mathrm{H}_{2} \mathrm{~S}$ was created. The matrix included varying the alumina and molybdenum oxide content, sulfur concentration, humidity level, and checking for cross-sensitivity to other gases. By doing this, NexTech hoped to collect engineering data that would be utilized to design the alpha bread-board prototypes.

Table 2 summarizes some of the data collected using this base composition. From this table a general trend can easily be observed. When the base resistance was below approximately 5 kohms the response to the introduction of $\mathrm{H}_{2} \mathrm{~S}$ was small, but still present; however, when the baseline in the background gases was greater than $5 \mathrm{kohms}$ the response to the presence of $\mathrm{H}_{2} \mathrm{~S}$ was much more prominent. This conclusion can best be demonstrated in the cases with $5 \mathrm{ppm}$ $\mathrm{H}_{2} \mathrm{~S}$ at $2 \%$ humidity and $10 \mathrm{ppm} \mathrm{H}_{2} \mathrm{~S}$ at $2 \%$ humidity because these conditions were the most common to numerous samples on numerous days (see Figs. 17 and 18). It is believed that this 
varying baseline and response is caused by a lack of complete dispersion of the alumina phase within the thick film deposited on the interdigitated electrodes. The main reason the $\mathrm{Al}_{2} \mathrm{O}_{3}$ phase was added to the ink initially was to increase the resistance of the ink such that better response readings could be attained at higher temperatures. Since all of the resistance change, or response, is caused by grain boundary effects, as discussed earlier, incomplete dispersion of the alumina would limit the impact it would have. Better dispersion of the alumina within the deposited films would lead to better grain boundary gas adsorption effects and therefore an enhancement in sensitivity. This enhanced sensitivity is seen much more distinctly in the samples with a baseline greater than the $5 \mathrm{kohms,} \mathrm{which} \mathrm{combined} \mathrm{with} \mathrm{the} \mathrm{knowledge,} \mathrm{that}$ alumina increases the baseline resistance, is why incomplete dispersion is suspected in the cases with low baseline resistances. This problem area is something that would be simply remedied in larger scale production of the inks. Currently the inks are made in very small amounts $(\sim 1 \mathrm{~g})$ and by increasing the amount produced and the processes that then become available, such as ball milling, the dispersion of the third phase should be no longer be problematic.

In order for the sensor to be able to fully characterize the amount of sulfur present the response between different amounts of $\mathrm{H}_{2} \mathrm{~S}$ should be distinguishable from one another. Fig. 19 shows day 2 of testing sensor 125-103A with the base composition of $10 \% \mathrm{Al}_{2} \mathrm{O}_{3}-5 \% \mathrm{MoO}_{3}-\mathrm{GDC}_{\text {. }}$ The background gas composition for this run is $61 \% \mathrm{~N}_{2}, 27 \% \mathrm{H}_{2}, 10 \% \mathrm{CO}_{2}$, and $2 \% \mathrm{H}_{2} \mathrm{O}$. The

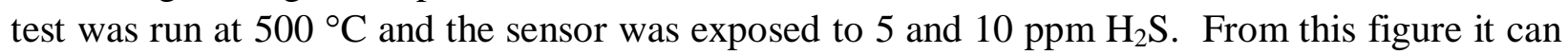
be seen that the sensor's response to the change was quick and repeatable as well as differing in size and shape for 5 and $10 \mathrm{ppm} \mathrm{H}_{2} \mathrm{~S}$, both of which are beneficial to further design. The sensor did recover a little slower than desired, but this is a problem that can be addressed in the future with continued development and miniaturization.

Cycling and extensive run times are concerns for the development of the rugged sulfur sensor. How a system changes and responds over a longer period of time is important. Figs. 20 and 21 are plots showing the performance of a single sensor to the same testing conditions over several days. Fig. 20 shows sensor 125-82D and Fig. 21 shows 125-103A. Both sensors are inks with the base composition of $10 \% \mathrm{Al}_{2} \mathrm{O}_{3}-5 \% \mathrm{MoO}_{3}-$ GDC. As immediately apparent, Fig. 4 resides entirely below $5 \mathrm{kohms,}$, where dispersion problems have caused the sensitivity to be limited, whereas Fig. 21 resides outside of that regime, allowing the sensor to be more responsive to the small amount of $\mathrm{H}_{2} \mathrm{~S}$ present. In Fig. 20 there is an obvious baseline shift as the testing continued from day to day. This shift was around $20 \%$ the first day and over $31 \%$ the second day; however, despite that baseline change the sensitivity of the sensor did not decrease or even vary much. The sensitivity bounced from almost $25 \%$ to up near $28 \%$ and then back to $25 \%$. In Fig. 21 the baseline shift was not as consistent as in Fig. 20. Initially, the drift increased the average baseline from $11.502 \mathrm{kohms}$ to $14.971 \mathrm{kohms}$, a shift of approximately $30 \%$, whereas the second day the average baseline decreased from $14.971 \mathrm{kohms}$ to $13.029 \mathrm{kohms}$, a change of $-12.97 \%$. As discussed later in the prototype design, a possible solution to the baseline drift is a Wheat-stone bridge can that be included in the electronics to account for it. The Wheat-stone bridge would contain the sensor on one leg and a mock sensor, containing only GDC, on the other. Therefore, if there is any drift caused by hydrogen cross sensitivity or other non sulfur causes, both the sensor and the mock sensor should change together and thus through constant comparison the only difference in the resistances will be from the active phases in the sensor responding, not other outside adverse affects. 
As just mentioned, cross-sensitivity of other gases is crucial to further design. If the sensor responds not only to sulfur, but to other gases as well, there must be techniques and modifications to the complete system to account for these interferences, for example the Wheatstone bridge. To verify if there is any cross-sensitivity of the sensor with respect to various levels of the background gases the levels of $\mathrm{CO}_{2}$ and $\mathrm{H}_{2}$ were increased and decreased by $~ 50$ vol. $\%\left(\mathrm{CO}_{2}\right.$ to $15 \%$ and $5 \% ; \mathrm{H}_{2}$ to $40 \%$ and $\left.14 \%\right)$. To maintain a constant flow rate throughout the system the amount of $\mathrm{N}_{2}$ was changed to account for the increase or decrease in $\mathrm{CO}_{2}$ or $\mathrm{H}_{2}$. Humidity level changes will be addressed separately. When the $\mathrm{CO}_{2}$ levels were changed there was little to no impact on the baseline resistance. For sensor 125-103D, with a baseline of 3.5 kohms, increasing or decreasing $\mathrm{CO}_{2}$ flow rates did not change the resistance at all; however, the impact of the $\mathrm{H}_{2}$ level was much more influential. When the $\mathrm{H}_{2}$ level was increased the baseline dropped from $3.4 \mathrm{kohms}$ to $2.1 \mathrm{kohms}$, while decreasing the $\mathrm{H}_{2}$ content saw the resistance increase from $3.1 \mathrm{kohms}$ to $5.8 \mathrm{kohms}$. This influence was repeated in sensor 125-103A. The impact on the resistance from $\mathrm{CO}_{2}$ was again minimal, yet $\mathrm{H}_{2}$ essentially doubled the resistance when the flow was decreased and almost halved it when the flow was increased, very similarly to how 125-103D responded. Although this cross-sensitivity was only checked on these two sensors, the impacts are so dramatically similar that there is high confidence that the conclusions are complete.

The ability or inability of a sensor to perform in humid environments has great impact on the future design of the complete system. In the case where water levels and content affect performance additional equipment would be required to decrease that humidity level before the sensor. This leads to larger systems preventing further miniaturization. Obviously, a sensor that can operate in both low and high levels of humidity this additional equipment is avoided, aiding in the miniaturization of the complete system. Fig. 22 is a plot of the effect that increasing the humidity level has on sensor 125-103D. From this figure the key observations and conclusions that are drawn are that the average baseline shifts up from $4.575 \mathrm{kohms}$ to $5.297 \mathrm{kohms,} \mathrm{a}$ change of approximately $15.8 \%$, and that the sensitivity of the sensor does not change between these two humidity levels. At $2 \% \mathrm{H}_{2} \mathrm{O}$ the sensitivity is $38.62 \%$ while at $28 \%$ humidity the sensitivity is $33.06 \%$. It should be noted that the time between the sulfur exposures where the baseline is bouncing is caused by getting the water bath to temperature and allowing for stabilization of the system to the new conditions.

Although other compositions were tested, both increasing and decreasing alumina and molybdenum oxide contents, not enough data was collected at these conditions to draw accurate conclusions. As a result, that data has been excluded, but could be continued with further development in the future to draw even stronger conclusions. 
Phase I Final Report

DOE Contract No. DE-FC26-02NT41576

November 18, 2003

Table 2. Summary of Results for Various $10 \% \mathrm{Al}_{2} \mathrm{O}_{3}-5 \% \mathrm{MoO}_{3}-\mathrm{GDC}$ samples at $500{ }^{\circ} \mathrm{C}$

\begin{tabular}{|c|c|c|c|c|c|c|}
\hline Date & Sample ID & $\left.\mathbf{H}_{\mathbf{2}} \mathbf{S}\right]$ & $\mathbf{\%}_{\mathbf{2}} \mathbf{O}$ & $\begin{array}{c}\Delta \mathbf{R} \text { Avg } \\
\text { (kohms) }\end{array}$ & $\begin{array}{c}\text { Baseline Avg } \\
\text { (kohms) }\end{array}$ & $\begin{array}{c}\text { \% Increase } \\
\text { over baseline }\end{array}$ \\
\hline Day 2 & $125-82 \mathrm{D}$ & $2.5 \mathrm{ppm}$ & $\sim 2-3$ & 0.443 & 2.354 & 18.81 \\
\hline Day 3 & $125-82 \mathrm{D}$ & $2.5 \mathrm{ppm}$ & $\sim 2-3$ & 0.773 & 2.759 & 28.00 \\
\hline Day 1 & $125-82 \mathrm{D}$ & $5 \mathrm{ppm}$ & $\sim 2-3$ & 0.247 & 1.687 & 14.65 \\
\hline Day 2 & $125-82 \mathrm{D}$ & $5 \mathrm{ppm}$ & $\sim 2-3$ & 0.520 & 2.091 & 24.86 \\
\hline Day 1 & $125-103 \mathrm{D}$ & $5 \mathrm{ppm}$ & $\sim 2-3$ & 0.362 & 2.408 & 15.05 \\
\hline Day 3 & $125-82 \mathrm{D}$ & $5 \mathrm{ppm}$ & $\sim 2-3$ & 0.706 & 2.514 & 28.08 \\
\hline Day 2 & $125-103 \mathrm{D}$ & $5 \mathrm{ppm}$ & $\sim 2-3$ & 0.782 & 3.218 & 24.31 \\
\hline Day 4 & $125-82 \mathrm{D}$ & $5 \mathrm{ppm}$ & $\sim 2-3$ & 0.835 & 3.295 & 25.34 \\
\hline Day 1 & $125-103 \mathrm{~A}$ & $5 \mathrm{ppm}$ & $\sim 2-3$ & 2.642 & 3.595 & 73.50 \\
\hline Day 1 & $125-103 \mathrm{C}$ & $5 \mathrm{ppm}$ & $\sim 2-3$ & 3.819 & 5.328 & 71.69 \\
\hline Day 1 & $125-63 \mathrm{~A}$ & $5 \mathrm{ppm}$ & $\sim 2-3$ & 10.290 & 10.593 & 97.14 \\
\hline Day 2 & $125-103 \mathrm{~A}$ & $5 \mathrm{ppm}$ & $\sim 2-3$ & 11.843 & 11.502 & 102.96 \\
\hline Day 5 & $125-103 \mathrm{~A}$ & $5 \mathrm{ppm}$ & $\sim 2-3$ & 19.637 & 13.029 & 150.72 \\
\hline Day 3 & $125-103 \mathrm{~A}$ & $5 \mathrm{ppm}$ & $\sim 2-3$ & 17.998 & 14.971 & 120.22 \\
\hline Day 4 & $125-82 \mathrm{D}$ & $5 \mathrm{ppm}$ & $\sim 28$ & 0.769 & 3.621 & 21.22 \\
\hline Day 4 & $125-103 \mathrm{~A}$ & $5 \mathrm{ppm}$ & $\sim 28$ & 18.291 & 12.970 & 141.03 \\
\hline Day 3 & $125-103 \mathrm{~A}$ & $5 \mathrm{ppm}$ & $\sim 28$ & 14.545 & 15.508 & 93.79 \\
\hline Day 4 & $125-103 \mathrm{~A}$ & $5 \mathrm{ppm}$ & $\sim 28$ & 18.860 & 15.799 & 119.37 \\
\hline Day 3 & $125-82 \mathrm{D}$ & $10 \mathrm{ppm}$ & $\sim 2-3$ & 1.123 & 2.921 & 38.45 \\
\hline Day 4 & $125-82 \mathrm{D}$ & $10 \mathrm{ppm}$ & $\sim 2-3$ & 1.126 & 3.044 & 36.98 \\
\hline Day 4 & $125-103 \mathrm{D}$ & $10 \mathrm{ppm}$ & $\sim 2-3$ & 1.767 & 4.575 & 38.62 \\
\hline Day 3 & $125-103 \mathrm{D}$ & $10 \mathrm{ppm}$ & $\sim 2-3$ & 1.593 & 4.578 & 34.79 \\
\hline Day 3 & $125-103 \mathrm{~A}$ & $10 \mathrm{ppm}$ & $\sim 2-3$ & 22.018 & 11.336 & 194.23 \\
\hline Day 2 & $125-103 \mathrm{~A}$ & $10 \mathrm{ppm}$ & $\sim 2-3$ & 22.104 & 11.903 & 185.70 \\
\hline Day 4 & $125-103 \mathrm{D}$ & $10 \mathrm{ppm}$ & $\sim 28$ & 1.752 & 5.297 & 33.06 \\
\hline Day 4 & $125-103 \mathrm{~A}$ & $10 \mathrm{ppm}$ & $\sim 28$ & 27.226 & 15.208 & 179.02 \\
\hline
\end{tabular}




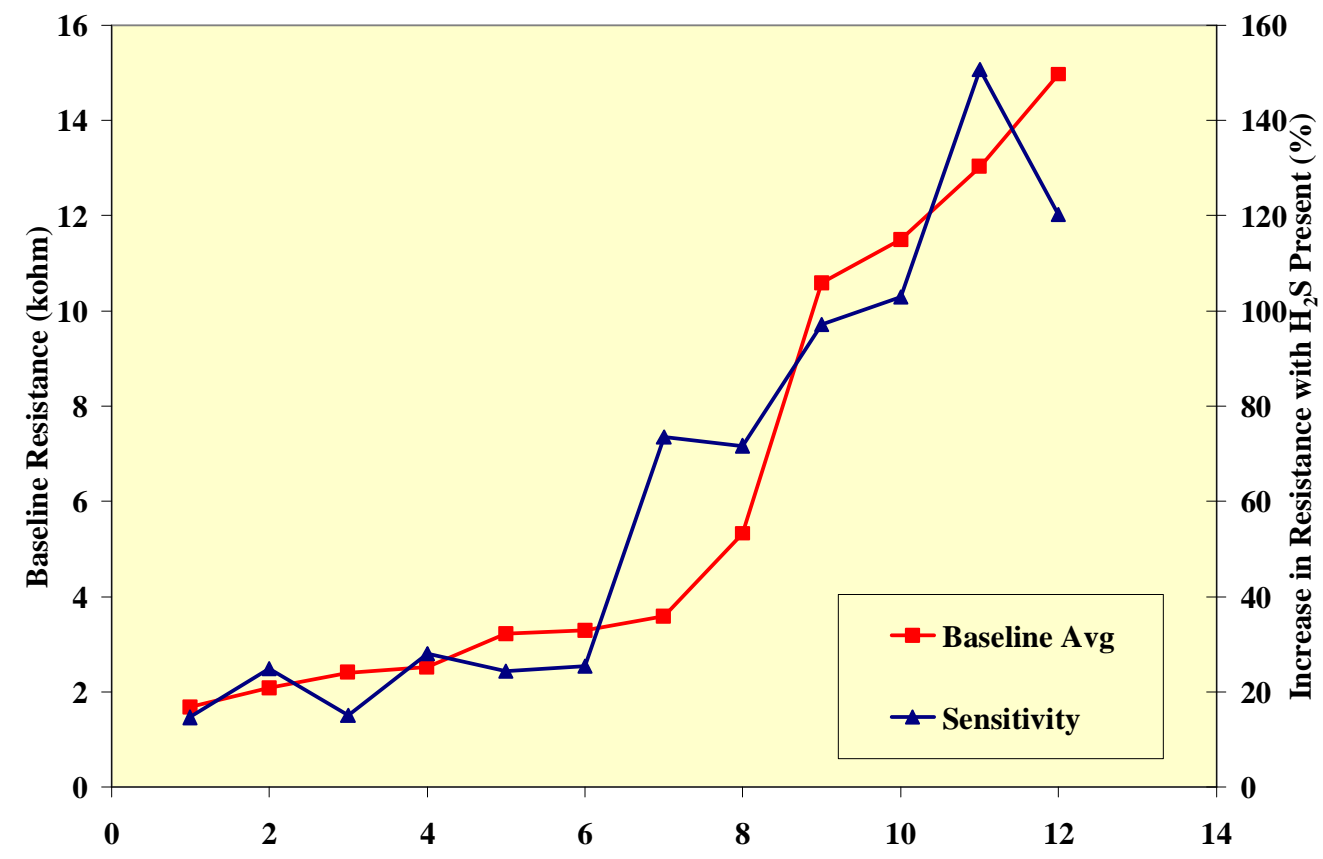

Fig. 17. Correlation between baseline and sensitivity for Base Sample in $5 \mathrm{ppm}_{2} \mathrm{~S}$ and $2 \%$ $\mathrm{H}_{2} \mathrm{O}$

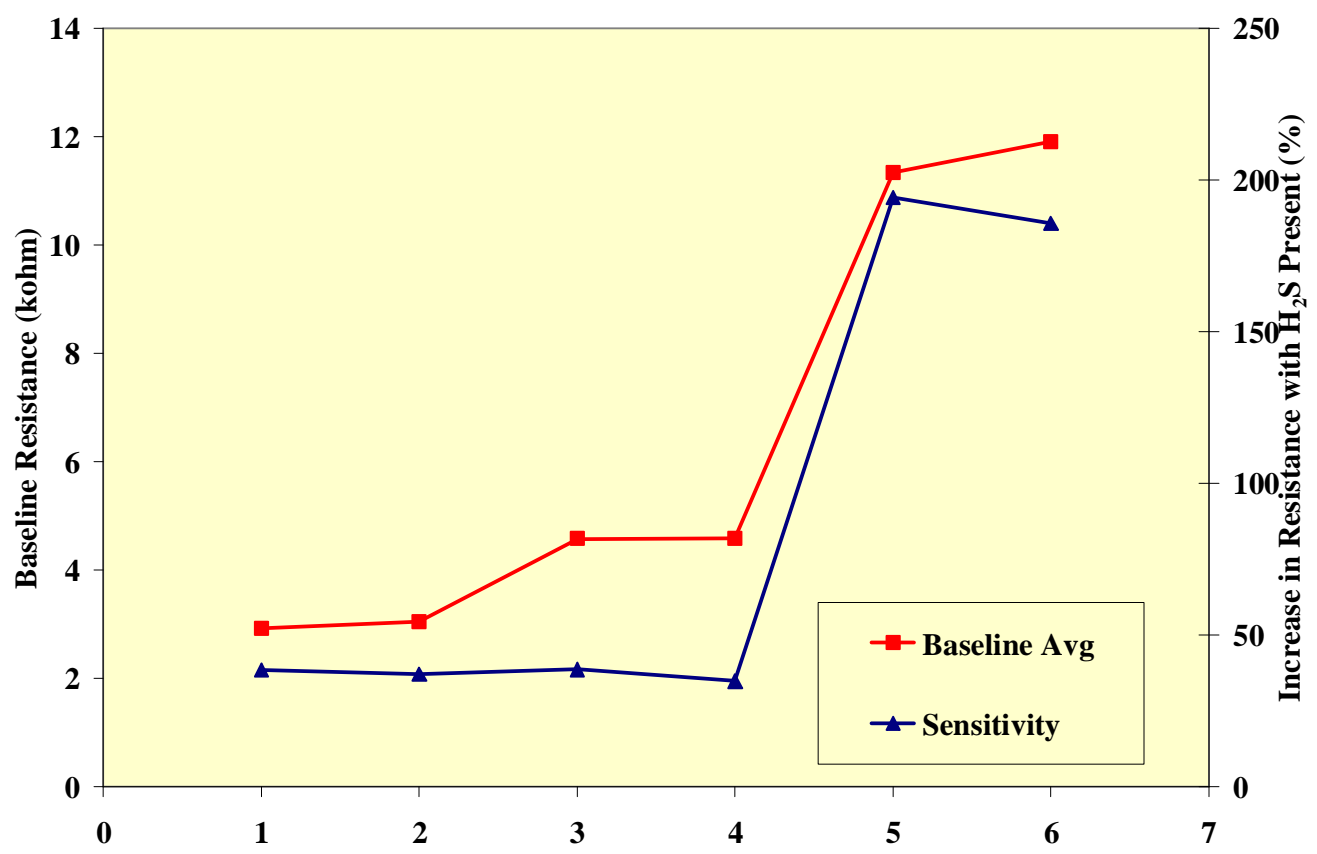

Fig. 18. Correlation between baseline and sensitivity for Base Sample in $10 \mathrm{ppm} \mathrm{H}_{2} \mathrm{~S}$ and $2 \%$ $\mathrm{H}_{2} \mathrm{O}$ 


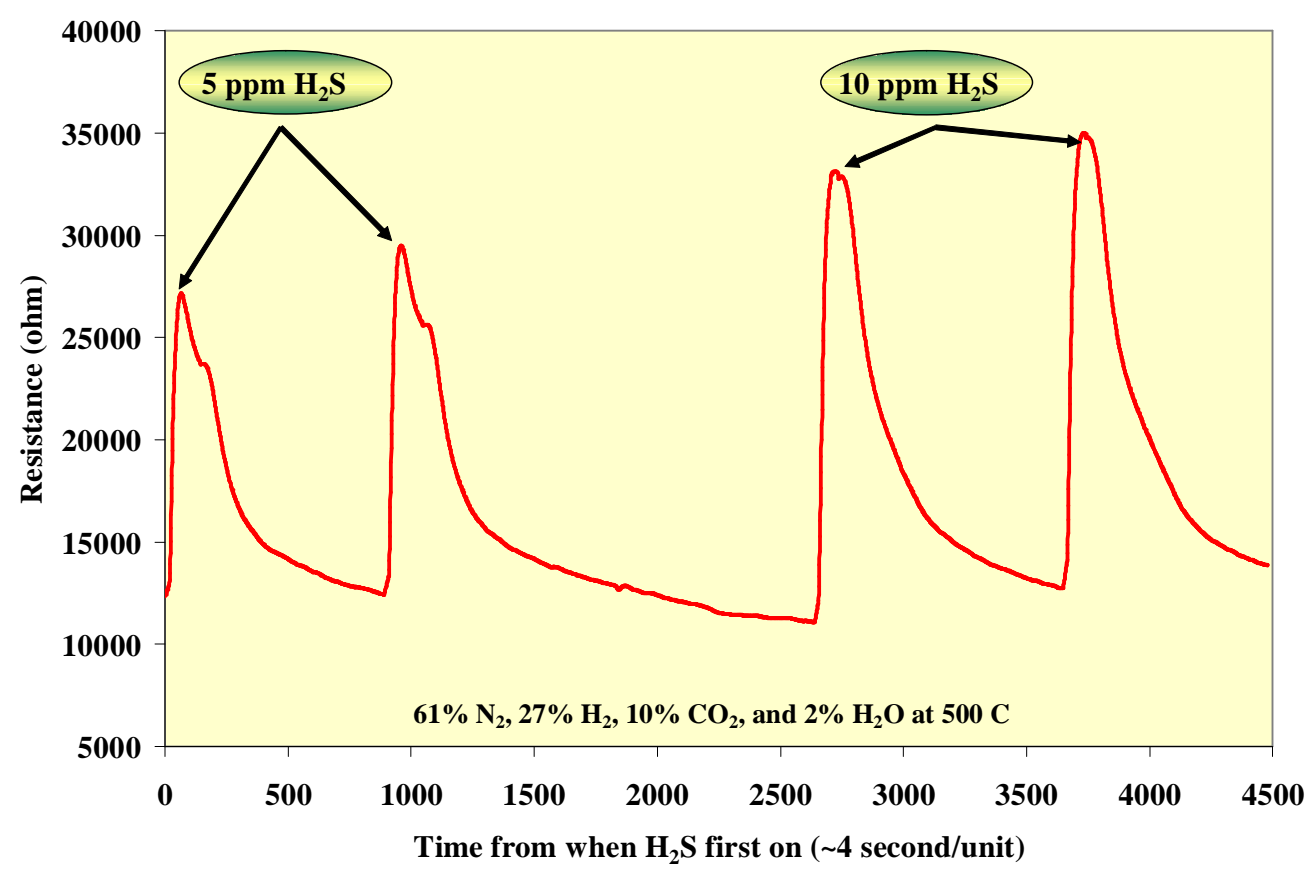

Fig. 19. Plot of the Response of Sensor 125-103A to 5 and $10 \mathrm{ppm}_{2} \mathrm{~S}$

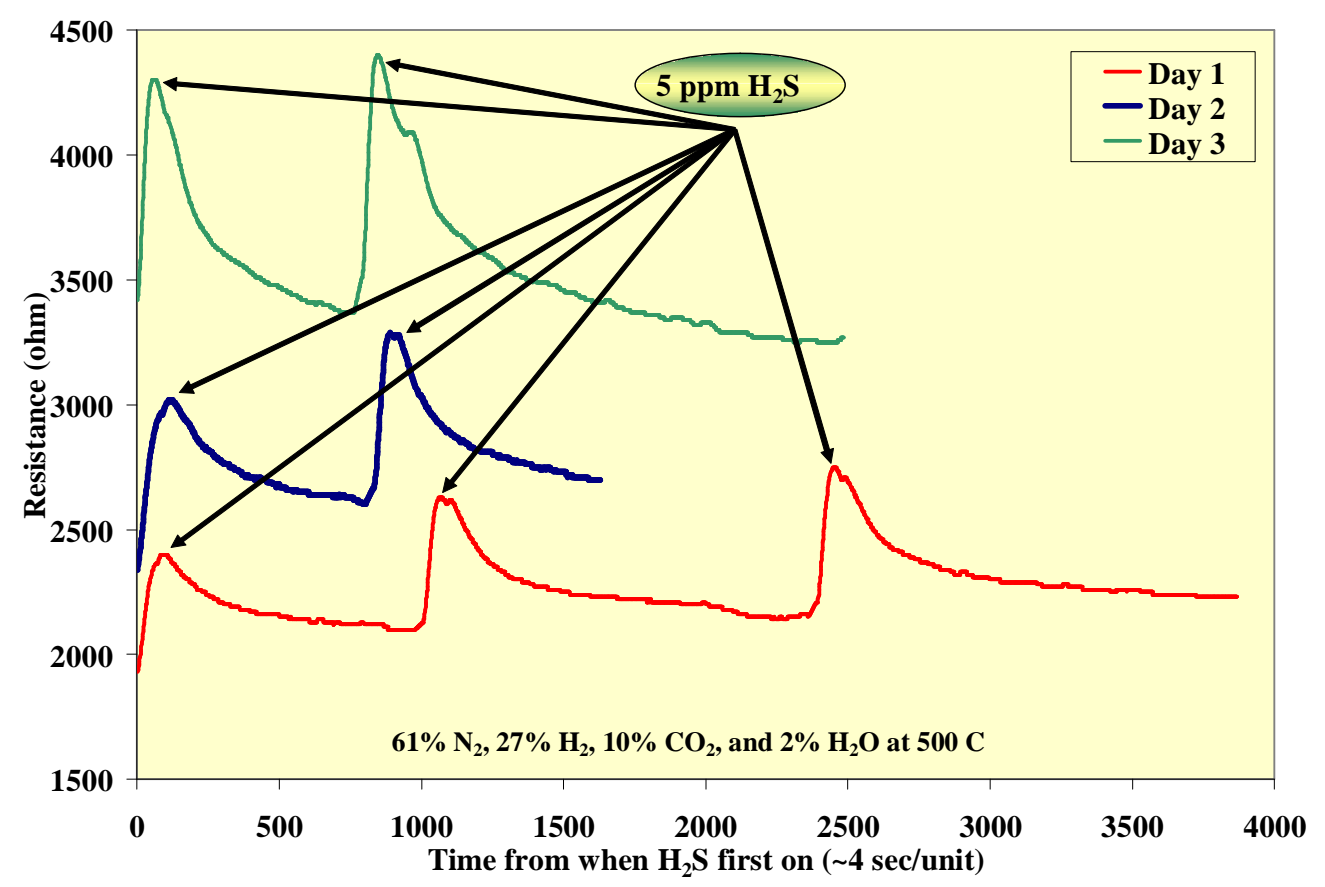

Fig. 20. Response of Sensor 125-82D over several days to $5 \mathrm{ppm} \mathrm{H}_{2} \mathrm{~S}$ 


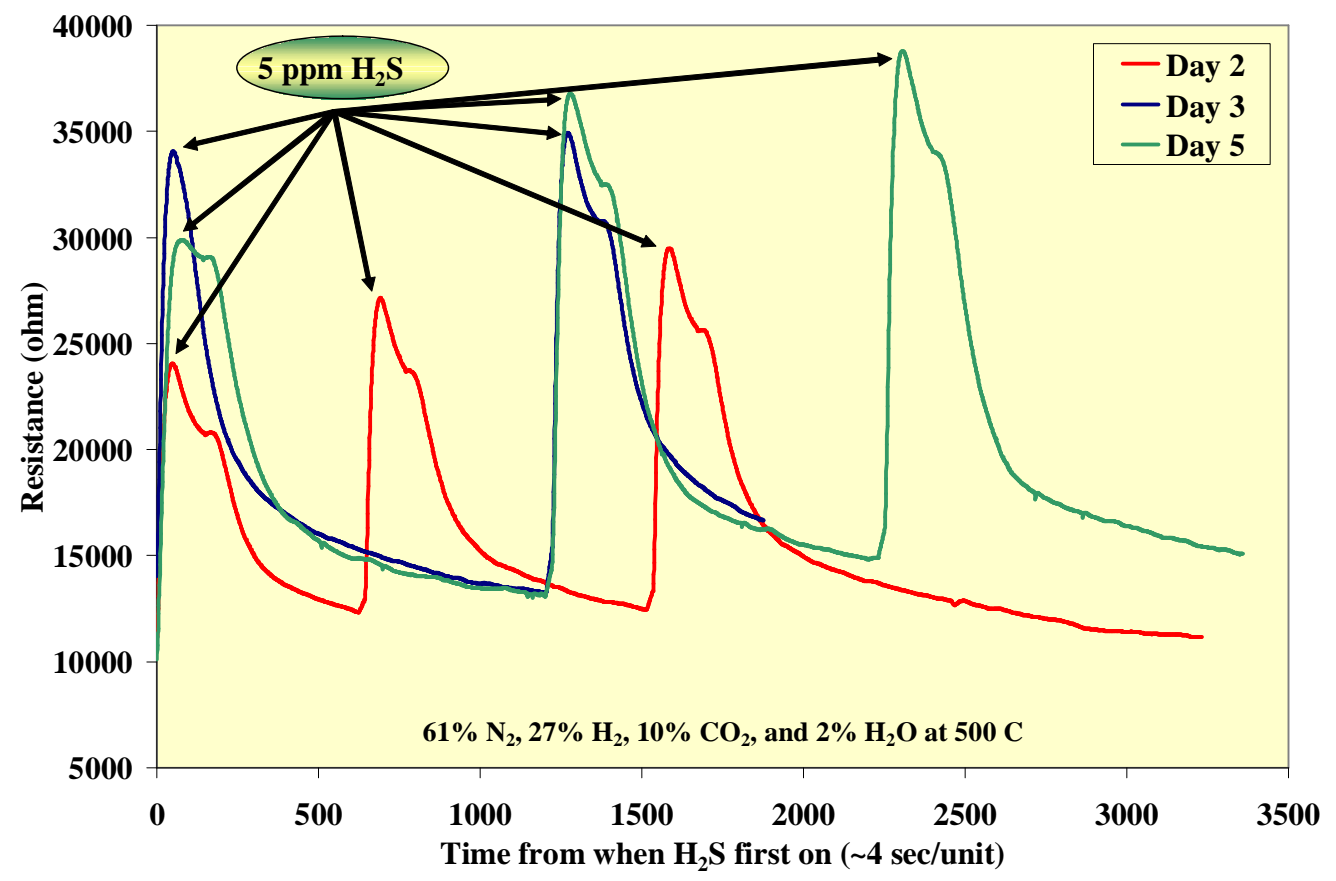

Fig. 21. Response of Sensor 125-103A over several days to $5 \mathrm{ppm}_{2} \mathrm{~S}$

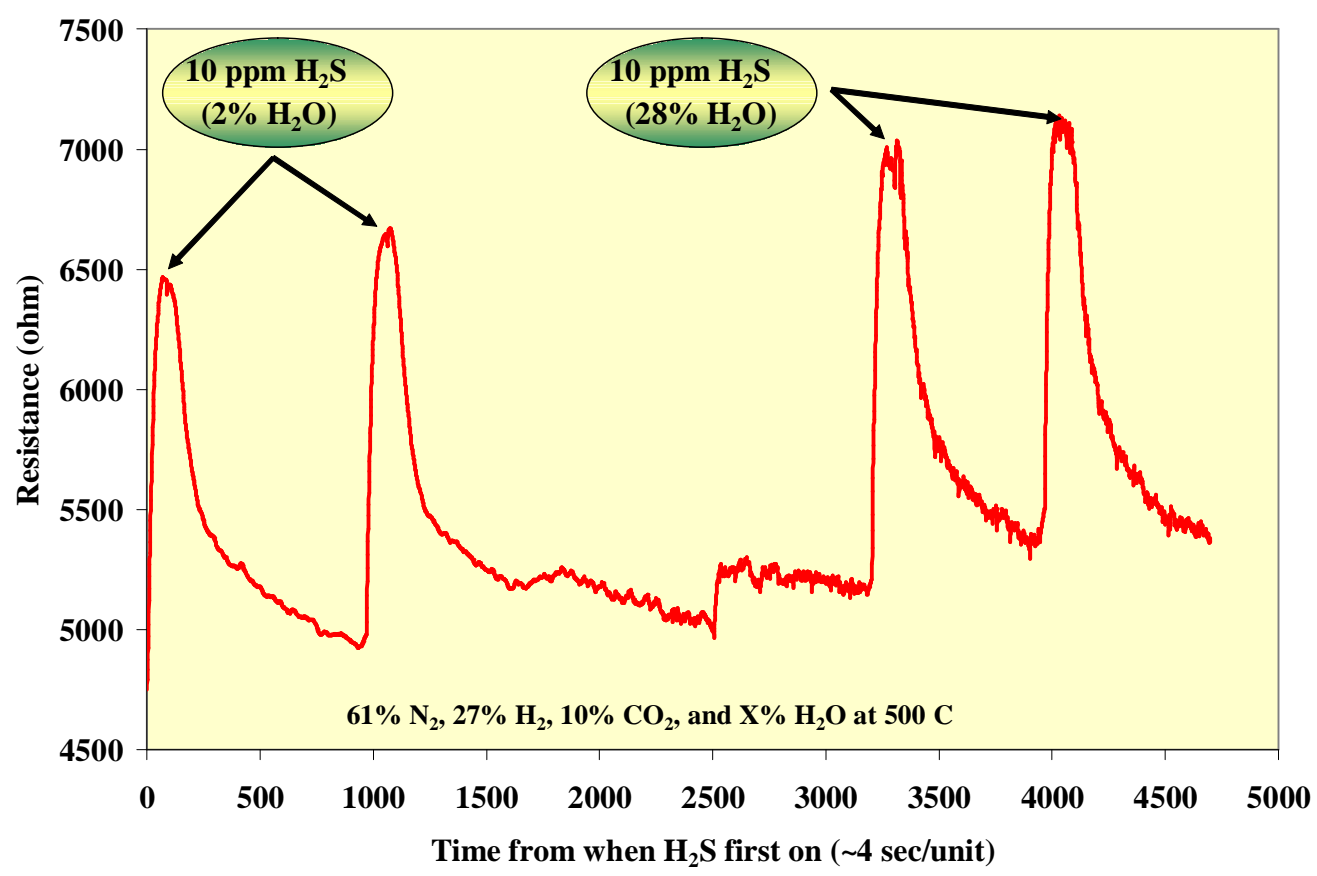

Fig. 22. Plot of the Response of Sensor 125-103D to $10 \mathrm{ppm} \mathrm{H}_{2} \mathrm{~S}$ at 5 and $10 \% \mathrm{H}_{2} \mathrm{O}$ 
The repeatable $\mathrm{H}_{2} \mathrm{~S}$ response obtained with the Moly-GDC sensors suggests the possibility of using these sensors in the harsh environments encountered in the SOFC fuel reformate. However, the high vapor pressure of $\mathrm{MoO}_{3}$ may be an issue during sensor preparation when attempting to maintain the correct relative amounts of base GDC and reactive $\mathrm{MoO}_{3}$ during the sensor film adhesion step. Also, oxidative environments in excess of $600^{\circ} \mathrm{C}$ could result in molybdenum oxide loss because of the high vapor pressure at these temperatures.

In order to determine the volatility of molybdenum oxide used as the reactive phase in GDC at the $10 \mathrm{wt} \%$ level, several samples were prepared with GDC and $\mathrm{MoO}_{3}(10 \mathrm{wt} \%)$ in a mortar and pestle and then subsequently calcined at 500,600,700 and $800^{\circ} \mathrm{C}$ for 1 hour. After calcining the powders were analyzed by X-ray diffraction with changes in peak intensity and position noted. Figure 23, shows the XRD pattern for the as mixed and calcined materials.

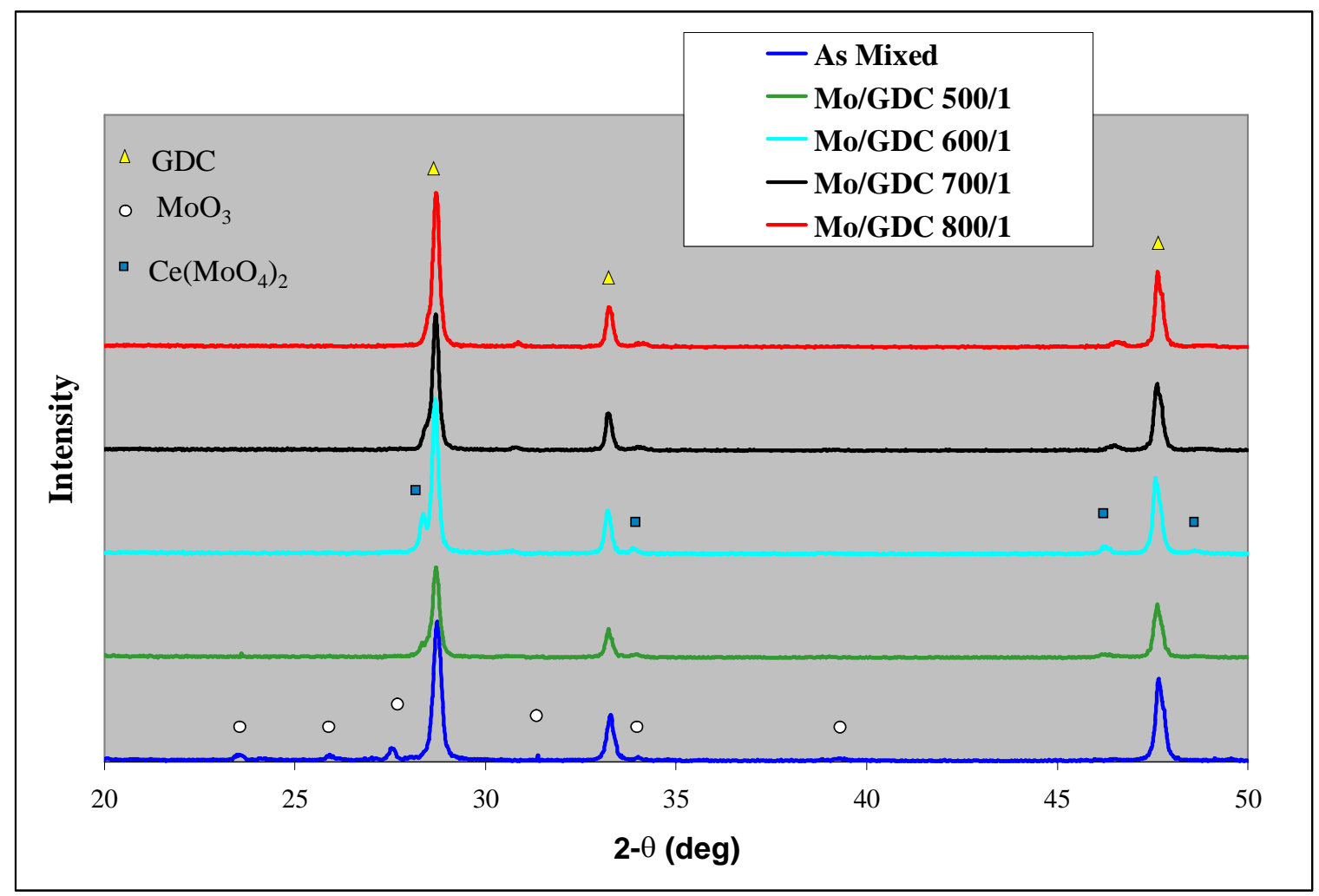

Fig. 23. XRD pattern for $10 \mathrm{wt} \% \mathrm{MoO}_{3}$ with GDC showing conversion of $\mathrm{MoO}_{3}$ into tetragonal $\mathrm{Ce}\left(\mathrm{MoO}_{4}\right)_{2}$.

Figure 23 shows the total conversion of $10 \mathrm{wt} \% \mathrm{MoO}_{3}$ into $\mathrm{Ce}\left(\mathrm{MoO}_{4}\right)_{2}$ at temperatures in excess of $500^{\circ} \mathrm{C}$. Considering the temperatures used to process the sensor films (in excess of $800^{\circ} \mathrm{C}$ ), it is possible that the $\mathrm{H}_{2} \mathrm{~S}$ sensitivity is due to the cerium molybdenum oxide phase formed during film adhesion. Further work will need to be done in order to isolate this phase and test its individual response to hydrogen sulfide. One approach would be to prepare phase pure molybdenum cerium oxide (perhaps via hydrothermal processing, co-precipitation techniques, etc.), prepare thick films, and test its response to hydrogen sulfide. 
NexTech feels that improvements in response/recovery time can be obtained through the use of thin films in a MEMs architecture and possibly through sensor thermal cycling (i.e. ramping the sensor to a higher temperature to reduce sulfide). For the sensor prototype development, NexTech envisions the use of a systems integration approach in order to develop the prototype. For the heater component of the sensor, NexTech will use an off the shelf PID controller and miniature tubular heater. The heater and controller system will be integrated with a PIC based microcontroller which will perform the sensor signal to analyte concentration conversion. For the chemi-resistor based hydrogen sulfide sensor, it will be necessary to convert the resistance signal into a read-out of $\mathrm{H}_{2} \mathrm{~S}$ concentration. The approach is based on Wheatstone bridge circuitry for converting chemi-resistor signals into voltage. This voltage is amplified to obtain a 0-5 Volt span. An analog to digital converter will be used to convert the analog $0-5 \mathrm{~V}$ signal into a binary code for microprocessor interfacing. A PIC based microcontroller will be used to interface the A-D converter and store sensor calibration curve algorithms. Figures 24 and 25, show the sensor circuit schematic and picture of the integrated PID controller, PIC processor and LCD display. For a feed-back control system the LCD display may not be needed, however, if it becomes necessary to monitor the performance of the desulfurization unit in a test bed, the addition of an LCD display may prove beneficial.

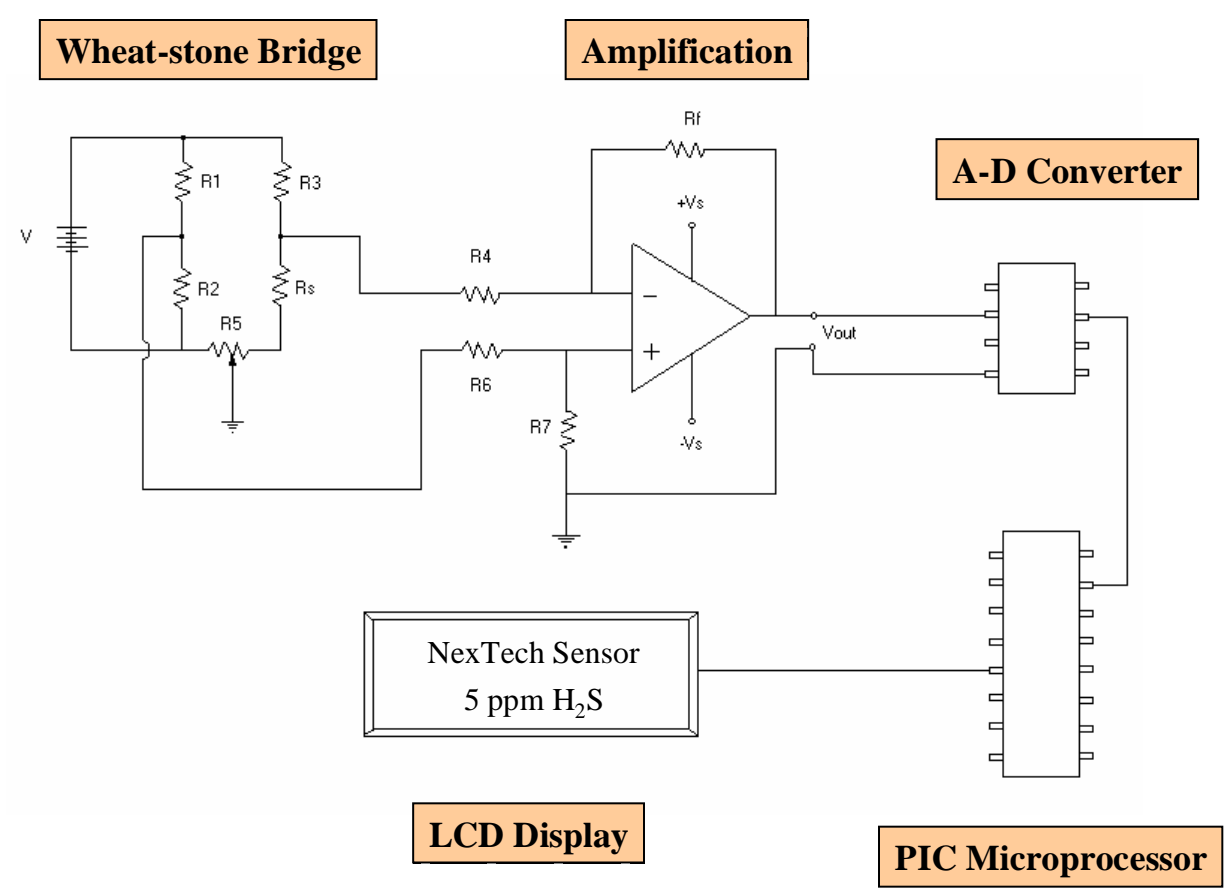

Fig. 24. Sensor signal conditioning circuit schematic showing Wheat-stone bridge, amplification, analog to digital, and PIC conversion. 
To address the issues of hydrogen cross-sensitivity, a second GDC sensor (w/o moly dopant) could be placed in the bridge at $\mathrm{R} 2$, therefore any changes in hydrogen concentration would be effectively nulled out.

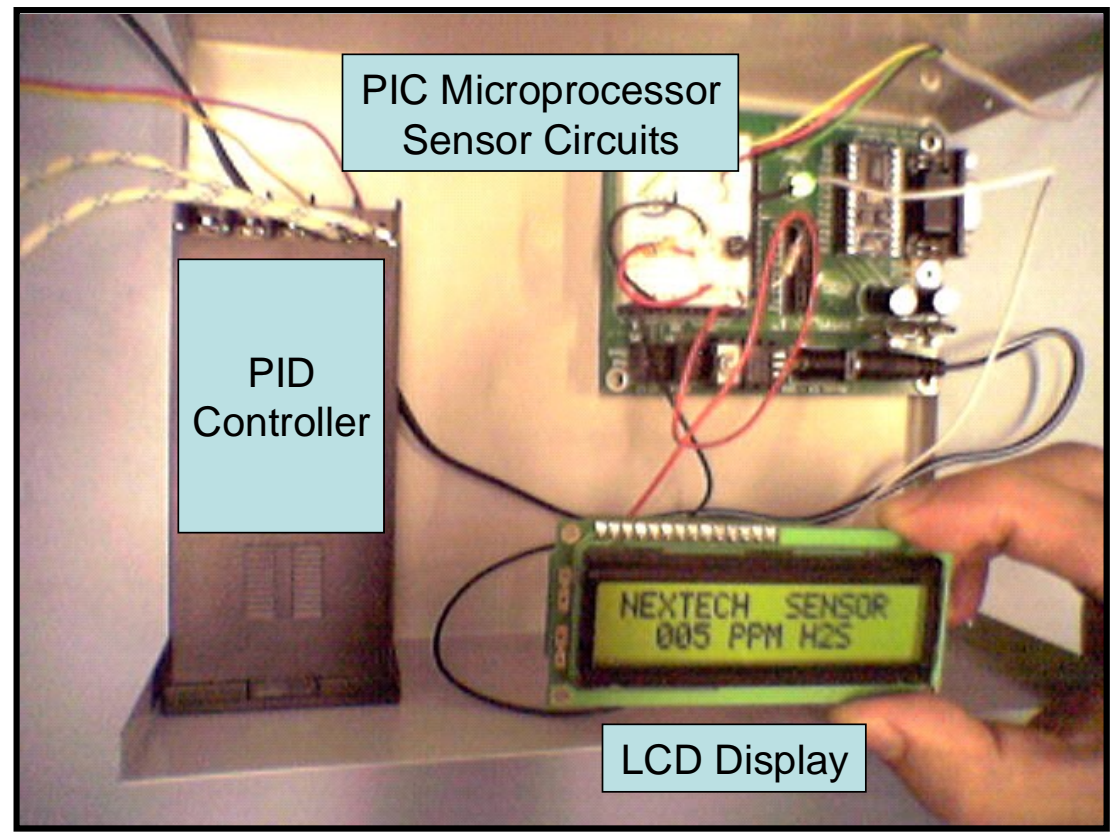

Fig. 25. Sensor heater and signal conditioning hardware.

\section{CONCLUSIONS}

By exploiting a novel combination of materials and measurement techniques, two sets of sensors were developed for monitoring light hydrocarbons (such as methane) and sulfur $\left(\right.$ as $\mathrm{H}_{2} \mathrm{~S}$ ) in a humidified syngas environment that is encountered in high temperature SOFC systems. A fuel cell kind of galvanic technique enabled the measurement of methane in simulated syngas environments up to $800^{\circ} \mathrm{C}$. On the other hand, a planar chemiresistor was employed to sense 1$10 \mathrm{ppm}$ of $\mathrm{H}_{2} \mathrm{~S}$ in $\mathrm{H}_{2}$-containing backgrounds. For the hydrogen sulfide sensors, NexTech found that the addition of a second insulating phase, when properly dispersed, provided enhanced sensitivity to $\mathrm{H}_{2} \mathrm{~S}$.

The critical issues with the hydrocarbon sensors include:

○ Response time, which may be improved through device miniaturization and electrode optimization ( small crystallite size).

- Methane sensitivity suppression due to high water contents at the SOFC anode could be addressed by removing the water to an adequate level.

For the hydrogen sulfide, the biggest issue is recovery time. This could be addressed by miniaturizing the device and instituting a thermal cycle where temperature elevation enhances sulfur desorption. This would require device miniaturization to reduce power requirements and 
thermal cycling time. Enhancements in hydrogen sulfide sensitivity and device complexity may be realized by isolating the $\mathrm{Ce}\left(\mathrm{MoO}_{4}\right)_{2}$ phase and evaluating its response to hydrogen sulfide. The results shown above demonstrate the validation of the proof-of-concept proposed in Phase I.

\section{REFERENCES}

None.

\section{BIBLIOGRAPHY}

1. A.-M. Azad, S.A. Akbar and L.B. Younkman, Electrochem. Soc. Interface 3, 31 (1994).

2. www.sierramonitor.com/model203.htm

3. www.chemsoc.org/chembytes/ezine/1997/nose.htm

4. www.cpec.nus.eedu.sg/myweb/newsletter/news4/development.html

5. www.amgas.com/sogpage.htm

6. www.nrcorp.com/NIHbrief.pdf

7. www.figarousa.com

8. www.sixth-sense.com

9. N.S. Lawrence, J. Davies and R.G. Compton, Talanta, 52, 771 (2000).

10. M. N. Rumyantseva, M. N. Bulova, T. A. Kuznetsova, L. I. Ryabova, A. M. Gas'kov, G. Loucaseau, and M. Labeau, Russian Journal of Applied Chemistry, 74, 434 (2001).

11. N. Miura, Y. Yan, G. Lu and N. Yamazoe, Sensors and Actuators, B34, 367 (1996).

12. D.H. Dawson, G.S. Henshaw and D.E. Williams, Sensors and Actuators, B26-27, 76 (1995).

13. V.V. Malyshev and A.V. Pislyakov, Sensors and Actuators, B47, 181 (1998).

14. T.L. Royster, Jr., D. Chatterjee, G.R. Paz-Pujalt and C.A. Marrese, Sensors and Actuators, B53, 155 (1998).

15. C. Yu, Y. Wang, K. Hua, W. Xing and T. Lu, Sensors and Actuators, B86, 259 (2002).

16. V.B. Shields, M.A. Ryan and R.M. Williams, Inst. Phys. Conf. Series \#142: Chapter 7, pp. 1067-70 (1996).

17. A. Arbab, A. Spetz and I. Lundstrom, Sensors and Actuators, B19, 15 (1993).

18. B.K. Narayanan, S.A. Akbar and P.K. Dutta, Sensors and Actuators, B87, 480 (2002).

19. A. Hashimoto, T. Hibino, K. Mori and M. Sano, Sensors and Actuators, B81, 5 (2001).

20. R. Mukundan, E.L. Broasha, D.R. Brown, and F.H. Garzon, Electrochem. Solid-State Lett. 2, 412 (1999).

21. A.Q. Pham and R.S. Glass, Hydrocarbon sensors and materials thereof, US Patent, \# $6,103,080$ (2000).

22. K. Ihokura and J. Watson, The Stannic Oxide Gas Sensor: Principles and Applications, CRC Press, Boca Raton, 1994.

\section{LIST OF ACRONYMS AND ABBREVIATIONS}

SOFC- Solid Oxide Fuel Cell

SECA- Solid State Energy Conversion Alliance

DOE- Department of Energy

GDC- Gadolinium doped Ceria

YSZ- Yttria Stabilized Zirconia 
XRD- X-Ray Diffraction

PIC- Peripheral Interface Controller

$\boldsymbol{\beta}$ - Beta

Figs.- Figures

CxHy- Hydrocarbon

ppm- Parts Per Million

$\mathbf{R b}$ - Resistance in baseline gas

Rg- Resistance in analyte gas

HCs- Hydrocarbons

IV-Current Voltage

LSCr- Srontium Substituted Lanthanum Chromite

$\mathbf{P O}_{2}$ - Oxygen Partial Pressure

OSC- Oxygen Storage Capacity

OCV-Open Circuit Voltage

Kohm- Kilo Ohm (1000 ohms)

wt\% - Weight Percent

vol\%- Volume Percent

ULHC- Unburned Light Hydrocarbon

MOS- Metal-Oxide Semiconductor

EMF- Electromotive Force

MFC- Mass Flow Controller

mM- Millimolar

$\mathbf{t}_{\mathbf{9 0}}$ - Response time at $90 \%$ of maximum signal

PEMFC- Proton Exchange Membrane Fuel Cell or Polymer Electrolyte Fuel Cell

SAW- Surface Acoustic Wave

MEM- Micro-electromechanical

PID- Proportional Integral Derivative

A-D- Analog to Digital

LCD- Liquid Crystal Display 